\title{
Effects of loss of perennial lake ice on mixing and phytoplankton dynamics: insights from High Arctic Canada
}

\author{
Julie VEILLETTE, Marie-Josée MARTINEAU, Dermot ANTONIADES, Denis SARRAZIN, \\ Warwick F. VINCENT
}

Département de Biologie \& Centre d'Études Nordiques (CEN), Université Laval, Québec City, Québec G1V 0A6, Canada E-mail: warwick.vincent@bio.ulaval.ca

\begin{abstract}
Perennially ice-covered lakes are well known from Antarctica and also occur in the extreme High Arctic. Climate change has many implications for these lakes, including the thinning and disappearance of their perennial ice cover. The goal of this study was to consider the effects of transition to seasonal ice cover by way of limnological observations on a series of meromictic lakes along the northern coastline of Ellesmere Island, Nunavut, Canada. Conductivity-temperature profiles during a rare period of ice-free conditions (August 2008) in these lakes suggested effects of wind-induced mixing of their surface freshwater layers and the onset of entrainment of water at the halocline. Sampling of the mixed layer of one of these meromictic lakes in May and August 2008 revealed a pronounced vertical structure in phytoplankton pigments and species composition, with dominance by cyanobacteria, green algae, chrysophytes, cryptophytes and dinoflagellates, and a conspicuous absence of diatoms. The loss of ice cover resulted in an $\mathbf{8 0}$-fold increase in water column irradiance and apparent mixing of the upper water column during a period of higher wind speeds. Zeaxanthin, a pigment found in cyanobacteria, was entirely restricted to the $<3 \mu \mathrm{m}$ cell fraction at all depths and increased by a factor of $2-17$, with the greatest increases in the upper halocline region subject to mixing. Consistent with the pigment data, picocyanobacterial populations increased by a factor of 3 , with the highest concentration $\left(1.65 \times 10^{8}\right.$ cells $\left.\mathrm{L}^{-1}\right)$ in the upper halocline. Chlorophyll a concentrations and the relative importance of phytoplankton groups differed among the four lakes during the open-water period, implying lakespecific differences in phytoplankton community structure under ice-free conditions.
\end{abstract}

\section{INTRODUCTION}

Ice-dominated lakes are a common feature of glacial environments in alpine and polar regions, and three classes of such lakes can be distinguished on the basis of their ice characteristics. Firstly, lakes with perennial ice cover are found in several parts of Antarctica and in the coldest parts of the Arctic. In these lakes, the ice persists throughout the year and any open water each year is limited to a narrow moat that may form around the edge of the lake in late summer. The best-known examples of this lake type are the perennially ice-capped lakes of the McMurdo Dry Valleys, Antarctica, that are typically covered by 3-5 m of ice (Green and Lyons, 2009, and references therein), with an extreme ice thickness of $19 \mathrm{~m}$ recorded in Lake Vida (Doran and others, 2003). Ward Hunt Lake, located at $83^{\circ} \mathrm{N}$ at the north of Ellesmere Island in the Arctic, was reported to have an ice cover of $4.1 \mathrm{~m}$ in 2003 (Antoniades and others, 2007), and an ice thickness of $5.5 \mathrm{~m}$ was measured on a lake in central Ellesmere Island at 830 ma.s.l. in the 1980s (Blake, 1989). Perennial ice cover has also been reported in northwest Greenland where Anguissaq Lake $\left(77^{\circ} \mathrm{N}\right)$ has up to $3.4 \mathrm{~m}$ of ice (Hobbie, 1984).

The second class of lakes comprises inland waters that intermittently retain their ice cover for $>1$ year. The bestknown examples are High Arctic Char Lake and Meretta Lake that typically lose their ice for 1-2 months each year, but occasionally retain their ice for the entire year (e.g. summer 1972; Schindler and others, 1974a,b). Similarly, Colour Lake, located further north on Axel Heiberg Island, was estimated to retain its ice cover about once every 6 years (Doran and others, 1996). Current warming trends and paleolimnological analyses suggest that multi-year ice cover is becoming increasingly rare in such lakes (e.g. Michelutti and others, 2003). Some Antarctic lakes (e.g. in the Vestfold Hills and Bunger Hills) may also intermittently retain their ice covers (Vincent and others, 2008a).

Most lakes in the Arctic have several months of ice-free conditions per year. In contrast to temperate lakes, these waters are covered by $1-2 \mathrm{~m}$ of ice for $>8$ months of the year. Examples of this third class of lakes include Toolik Lake, lying at $68^{\circ} \mathrm{N}$ in Alaska, which is usually ice-free from July through September and has an ice-cover thickness that may reach $1.4 \mathrm{~m}$ (http://ecosystems.mbl.edu/ARC). Numerous lakes located between the ice-cap margin and the coast in West Greenland $\left(66-67^{\circ} \mathrm{N}\right)$ are ice-covered for 9 months $\mathrm{a}^{-1}$ (Anderson and others, 2001). Seasonal ice cover also occurs in the warmest parts of Antarctica, including maritime Antarctica and certain coastal areas of the continent (Vincent and others 2008a). For example, Ace Lake and other meromictic (i.e. permanently stratified) lakes in the Vestfold Hills of East Antarctica are known to often lose their ice in the summer (Gibson, 1999).

Lake ice phenology is highly responsive to climatic variations and has been identified as one of the strongest limnological indicators of climate change (Vincent and others, 2008a). Recent warming in the Northern Hemisphere has resulted in shorter lake ice cover duration, with earlier break-up dates and, to a lesser extent, later freezing (Magnuson and others, 2000; Duguay and others, 2006). Thinning of the ice cover of an Antarctic lake has been linked to the extent of air temperatures above freezing (Wharton and others, 1992), while thinning and complete 

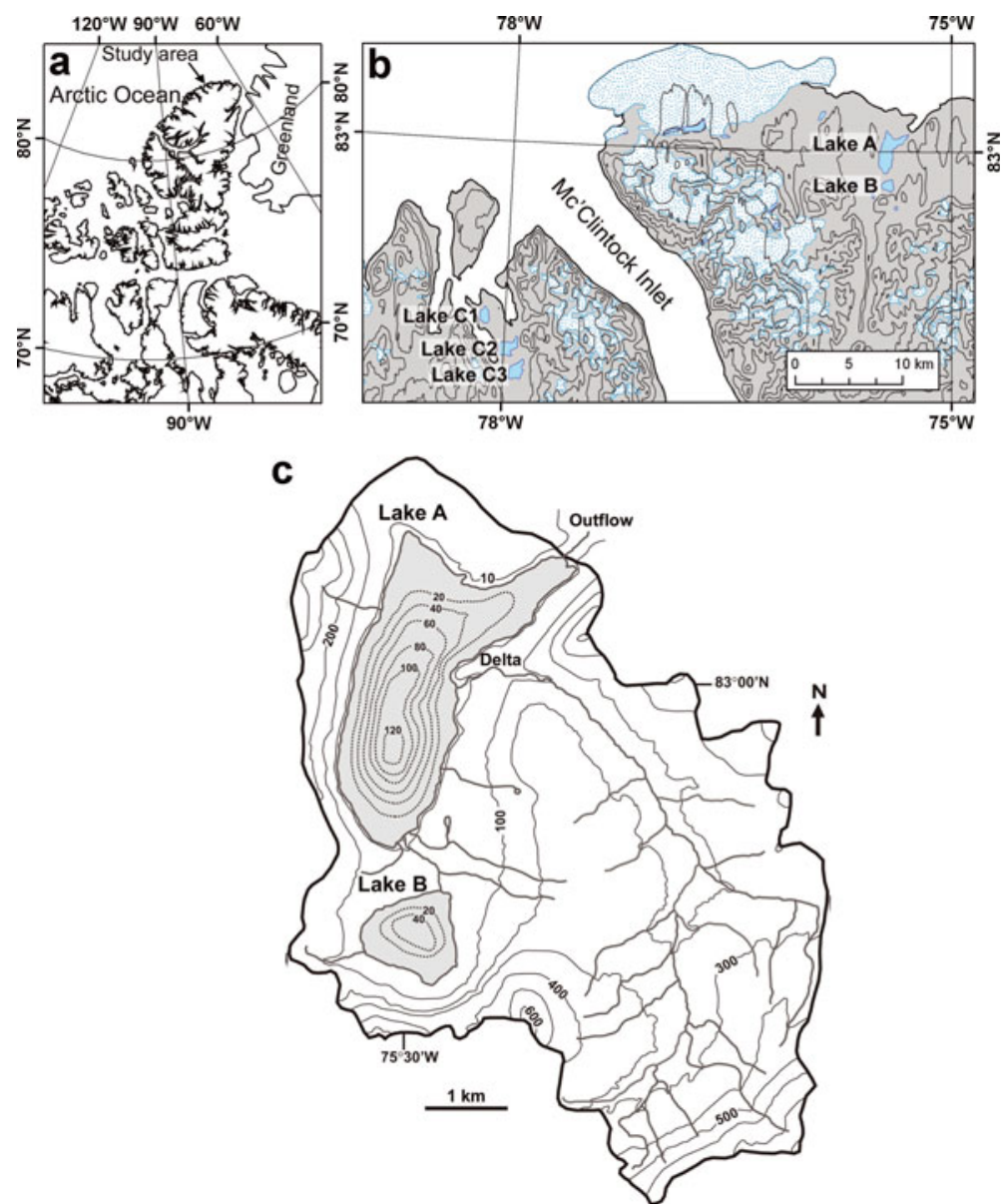

Fig. 1. (a) Location map of the study area on northern Ellesmere Island with (b) a close-up of the study area. (c) Map of Lake A and Lake B catchments.

melt of the ice cover of previously perennially ice-capped High Arctic and maritime Antarctic lakes have been attributed to warming climates (Quayle and others, 2002; Van Hove and others, 2006; Mueller and others, 2009).

Our objective in this study was to evaluate the implications for ecosystem structure and function of the increasingly observed loss of perennial lake ice. Specifically, we examined a meromictic High Arctic lake, Lake A, that appears to be in transition from perennial ice to seasonally ice-free conditions. To understand the effects of a shift towards seasonal ice cover, we focused on the water column properties and phototrophic community structure in the section most affected by wind-induced mixing (0-12 m), where almost all interannual variability and most of the in situ production of chlorophyll a occurs (Antoniades and others, 2009). We assessed changes in biomass and community composition with high-performance liquid chromatography (HPLC) analysis of photosynthetic pigments and microscopic analysis of the phytoplankton community. We extended these measurements to three other meromictic lakes in the region to investigate whether general trends could be identified.

\section{METHODS}

\section{Study area}

Lake $\mathrm{A}\left(83^{\circ} 00^{\prime} \mathrm{N}, 75^{\circ} 30^{\prime} \mathrm{W}\right)$, Lake $\mathrm{B}\left(82^{\circ} 58^{\prime} \mathrm{N}, 75^{\circ} 26^{\prime} \mathrm{W}\right)$, Lake $\mathrm{C} 1\left(82^{\circ} 51^{\prime} \mathrm{N}, 78^{\circ} 12^{\prime} \mathrm{W}\right)$ and Lake $\mathrm{C} 2\left(82^{\circ} 50^{\prime} \mathrm{N}\right.$, $78^{\circ} 05^{\prime} \mathrm{W}$ ) (unofficial names) are meromictic lakes located on the northwestern coast of Ellesmere Island, Nunavut, Canada (Fig. 1). They were formed after isostatic rebound caused the isolation of fiords from the Arctic Ocean several thousand years ago; lakes located further inland at a higher elevation became isolated and stratified earlier (Jeffries and others, 1984; Ludlam, 1996a,b). Lake A $\left(4.9 \mathrm{~km}^{2}\right.$ in surface area) and Lake $B\left(1 \mathrm{~km}^{2}\right)$ are located in the same valley, and Lake B's outlet flows into Lake A. The catchments of Lake A $\left(37 \mathrm{~km}^{2}\right)$ and Lake $B\left(5 \mathrm{~km}^{2}\right)$ contain no glaciers. Lake C1 $\left(1.1 \mathrm{~km}^{2}\right.$ in surface area) and Lake C2 $\left(1.8 \mathrm{~km}^{2}\right)$ are located in Taconite Inlet $\sim 40 \mathrm{~km}$ to the west. The catchment of Lake C1 is small $\left(3.3 \mathrm{~km}^{2}\right)$ and contains no glaciers, while that of Lake C2 is glacierized and larger $\left(23.5 \mathrm{~km}^{2}\right)$.

\section{Climate}

Air temperature, incident solar irradiance in the photosynthetically active radiation (PAR) waveband (400$700 \mathrm{~nm}$ ), and wind speed and direction at Lake A were recorded at $3 \mathrm{~m}$ above the ground with a tripod design automatic weather station (Campbell Scientific Inc.) that has been in operation since August 2003 as part of the SILA (in Inuktitut, 'climate and all things around us') monitoring network of Centre d'Études Nordiques (CEN). This was located at $83^{\circ} 0.14^{\prime} \mathrm{N}, 75^{\circ} 23.38^{\prime} \mathrm{W}, 10 \mathrm{~m}$ from Lake $\mathrm{A}$ on the eastern stream delta (Fig. 1c). Measurements were taken every minute by a Campbell Scientific CR10X data logger and output as hourly averages, or hourly maxima (maximum wind speed). 
Table 1. Ice and snow thicknesses for Lake A from 1969 to 2009. - : information not available

$\begin{array}{llll}\text { Date of profiling } \begin{array}{c}\text { Ice } \\ \text { thickness }\end{array} & \begin{array}{c}\text { Snow } \\ \text { depth }\end{array} & \text { Source }\end{array}$

$\mathrm{m} \quad \mathrm{cm}$

$\begin{array}{lcrc}1 \text { May 1969 } & 2.0 & - & \text { Hattersley-Smith and others (1970) } \\ \text { 10 May 1982 } & 2.0 & - & \text { Jeffries and others (1984) } \\ \text { 14 May 1983 } & 2.0 & - & \text { Jeffries and Krouse (1985) } \\ \text { 5 June 1999 } & 2.0 & 52 & \text { Belzile and others (2001) } \\ 1 \text { August 2001 } & 1.0 & 0 & \text { Van Hove and others (2006) } \\ 1 \text { August 2003 } & \text { thin } & 0 & \text { Mueller and others (2009) } \\ \text { 4 August 2004 } & 1.0 & 0 & \text { Mueller and others (2009) } \\ \text { 26 May 2005 } & 1.5 & 60 & \text { Antoniades and others (2009) } \\ \text { 30 May 2006 } & 1.3 & 50 & \text { Antoniades and others (2009) } \\ \text { 13 July 2007 } & 1.0 & 0 & \text { Mueller and others (2009) } \\ \text { 30 May 2008 } & 1.2 & 50 & \text { This study } \\ \text { 20 August 2008 } & 0 & 0 & \text { This study } \\ 6 \text { July 2009 } & 1.6 & 4 & \text { This study } \\ \end{array}$

\section{Field sampling}

We visited Lake A on 30 May and 20 August 2008, and Lakes B, C1 and C2 on 24 August 2008. There was an ice cover of $1.2 \mathrm{~m}$ and a snow cover of $50 \mathrm{~cm}$ on Lake $A$ at the time of sampling in May while all sampled lakes were icefree in August. Additional profiling and hydrological measurements at Lake A were done on 13 July 2007 (1 m of ice) and 6 July 2009 ( $1.6 \mathrm{~m}$ of ice and $4 \mathrm{~cm}$ of snow). Water column profiles were taken with an XR-420 or XR620 CTD (conductivity-temperature-depth profiler; RBR Ltd, Ottawa, Ont., Canada) through a drilled hole or from a Zodiac inflatable boat. Water samples for nutrient, pigment and microscopic analyses were taken using a 6.2 L Kemmerer sampler, transferred to acid-washed, opaque $20 \mathrm{~L}$ plastic containers and stored in the dark at $4{ }^{\circ} \mathrm{C}$ until processing. Sampling depths were selected in relation to the salinity profile to target the surface freshwater layer in all lakes $(2 \mathrm{~m})$, and additional samples were taken through the freshwater layer, upper halocline and deeper in the water column when logistical conditions were favourable. Lake A inflow and outflow conductivity data were taken with a portable $\mathrm{pH}$-conductivity-temperature probe (Oakton Instruments, Vernon Hills, IL, USA), with the exception of the outflow measurements on 20 August 2008 that were taken with an XR-620 CTD. Measured conductivity normalized at $25^{\circ} \mathrm{C}, C_{25}$, was converted to salinity, $S$, via the algorithm $S=0.65 \times 10^{-3} C_{25}\left(\mu \mathrm{S} \mathrm{cm}^{-1}\right)$ (Pawlowicz, 2008). Flow velocities were measured with a Swoffer Instruments 2100 STDX flowmeter (Seattle, WA, USA). Water samples for nutrient (TN, $\left.\mathrm{TP}, \mathrm{NO}_{3}{ }^{-}, \mathrm{NO}_{2}{ }^{-}, \mathrm{SRP}\right)$ analyses were processed at the National Laboratory for Environmental Testing (NLET, Burlington, Ont., Canada).

\section{Hydrological calculations}

Annual discharge of Lake A was estimated by two methods. First, it was calculated assuming complete melting of the end-of-winter snowpack, roughly estimated as the lake snow depth of $0.5 \mathrm{~m}$ observed in May each year (Table 1) extrapolated to the whole catchment plus lake, and using a snow water equivalent of 0.21 (Belzile and others, 2001). To this were added the water equivalent precipitation averages for 1971-2000 during June (11.1 mm), July
$(27.8 \mathrm{~mm})$ and August $(21.2 \mathrm{~mm})$ from Alert (the closest weather station of Environment Canada, located $193 \mathrm{~km}$ to the east of Lake A; http://www.weatheroffice.gc.ca). For this first-order estimate, surface evaporation was considered negligible. This gave an annual total of $165 \mathrm{~mm}$, similar to the $154 \mathrm{~mm}$ average annual precipitation at Alert. Secondly, discharge was estimated from current data measured at the single outflow of Lake A in July 2007. Water residence times of the meltwater layer present during the melt period at Lake A (uppermost 2-3 m of water from the profiles of July 2007 and 2009) and of the entire freshwater layer during openwater conditions $(0-10 \mathrm{~m})$ were estimated by dividing the volume of the layer by annual discharge. Mean ice-cover thickness in July was $1.3 \mathrm{~m}(1.0 \mathrm{~m}$ in 2007 and $1.6 \mathrm{~m}$ in 2009) and the maximum depth at which the low-conductivity meltwater was detectable was $3 \mathrm{~m}$.

\section{Stability indices}

Water column stability indices were calculated to examine the potential of mixing of the entire water column and of the surface layer of Lake A after ice-out. Calculations were made with the profile data of May 2008 and the wind conditions during August 2008. The Brünt-Väisälä frequency, N, was calculated following Caplanne and Laurion (2008), and the Wedderburn number, W, following Kalff (2003). Water density was calculated according to the sea-water equation from UNESCO (1981) since salinity was >0.4 ppt for the surface layer $(0-10 \mathrm{~m})$ and $>1$ ppt below $10 \mathrm{~m}$.

\section{Solar radiation}

Solar irradiance (PAR) reaching the water column of Lake A was calculated from the hourly measurements at our weather station at Lake A. Daily totals were summed to calculate the cumulative incident PAR reaching Lake A up to the date of water-column samplings. Then PAR immediately under the ice in May 2008 was calculated from snow albedo and ice attenuation coefficients from Belzile and others (2001). PAR immediately under the water surface in August 2008 was calculated from a water albedo of $8.6 \%$ for a solar elevation of $33^{\circ}$ at noon at Lake A (Kirk, 1994; Belzile and others, 2001). As another measure of light availability, we calculated mean water-column irradiance for the sampling days for the region $0-12 \mathrm{~m}$ (or under the ice to $12 \mathrm{~m}$ ). This encompasses the section of the water column potentially affected by wind-induced mixing. We calculated mean water-column irradiance with the water extinction coefficient of Belzile and others (2001) and the equation used by Vincent (1983).

\section{Photosynthetic pigment analyses}

Water samples $(0.35-1.05 \mathrm{~L})$ for pigment analyses were filtered with $25 \mathrm{~mm}$ diameter GF/F glass-fibre filters (nominal pore size $0.7 \mu \mathrm{m}$ ) that were frozen immediately in the field in a dry shipper $\left(-80^{\circ} \mathrm{C}\right)$ and subsequently stored in a $-80^{\circ} \mathrm{C}$ freezer until analysis. For analysis of the picoplankton fraction, the samples $(0.5-2.0 \mathrm{~L})$ were pre-filtered through a $3.0 \mu \mathrm{m}, 47 \mathrm{~mm}$ diameter Nuclepore filter prior to being filtered with the GF/F. Pigments were extracted from the frozen phytoplankton filters by sonication in $2.5 \mathrm{~mL}$ of $95 \%$ methanol, cleared by centrifugation, and filtered with PTFE syringe filters (pore size $0.2 \mu \mathrm{m}$ ) into HPLC vials. The extracts were then put under argon and kept at $4{ }^{\circ} \mathrm{C}$ in the dark in the HPLC autosampler to prevent pigment degradation. Shortly following extraction, $100 \mu \mathrm{L}$ of phytoplankton 

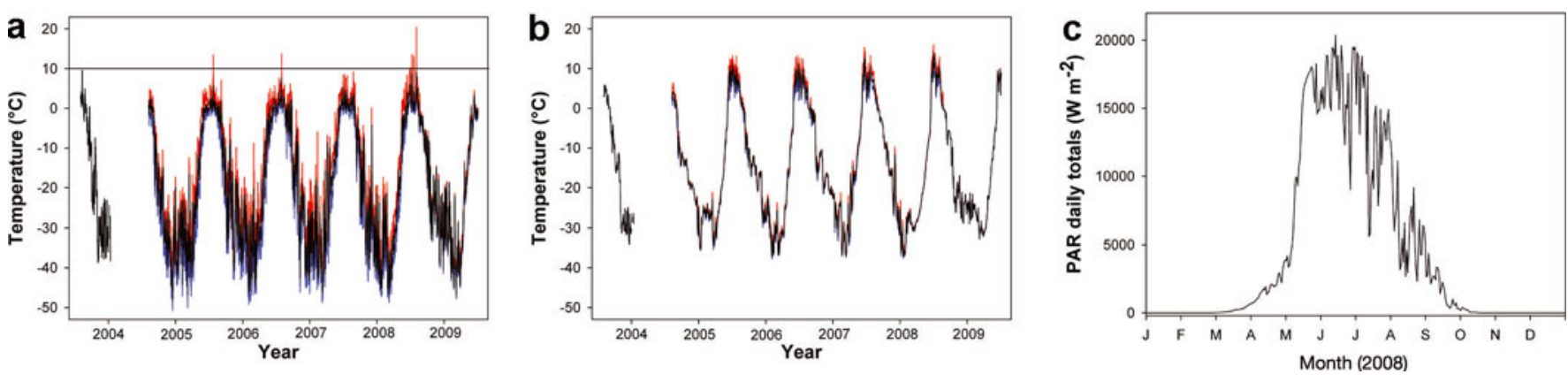

Fig. 2. Mean (black), maximum (red) and minimum (blue) (a) daily air temperatures and (b) daily ground (at $20 \mathrm{~cm}$ ) temperatures from 2003 to 2009, and (c) the 2008 annual cycle of the daily totals in PAR at the Lake A weather station.

pigment extracts were injected into a Varian ProStar HPLC system equipped with a Symmetry C8 column. The solvent protocol followed that of Zapata and others (2000). Chlorophylls were detected by fluorescence (excitation $440 \mathrm{~nm}$, emission $650 \mathrm{~nm}$ ) and carotenoids by photodiodearray (PDA) spectroscopy $(350-750 \mathrm{~nm})$ set to a slit width of $2 \mathrm{~nm}$. Absorbance chromatograms were obtained at $450 \mathrm{~nm}$ for carotenoids and $476 \mathrm{~nm}$ for bacteriochlorophylls. Standards for identification (based on PDA spectra and retention times) and quantification (using calibration coefficients) of pigments were obtained from Sigma Inc. (St Louis, MO, USA) (Chl $a, \mathrm{Chl} b, \beta, \beta$-carotene) and DHI Water \& Environment (Hørsholm, Denmark) (alloxanthin, Chl $C_{2}$ diadinoxanthin, fucoxanthin, lutein, violaxanthin, zeaxanthin) to calibrate our HPLC. Antheraxanthin and MgDVP were identified from a culture of Micromonas sp. (CCMP, West Boothbay Harbor, ME, USA); antheraxanthin was quantified using the extinction coefficient from the literature (Jeffrey and others, 1997), and MgDVP using the calibration coefficient of $\mathrm{Chl} C_{2}$. No commercial standard or culture was available to confirm the identification of $\mathrm{Chl} c_{1}$ or $\mathrm{Chl} c_{3}$; these pigments were identified based on PDA spectra (when present in sufficient concentrations) (Jeffrey and others, 1997) and retention times on the fluorometer chromatogram (Zapata and others, 2000), and quantified using the calibration coefficient of $\mathrm{Chl} \mathrm{C}_{2}$. Chlorophyllide a was identified based on its retention time on the fluorometer chromatogram (Zapata and others, 2000). No commercial standards for the photosynthetic bacterial pigments bacteriochlorophyll-e and isorenieratene were available, and these were identified and quantified from published spectra and coefficients (Borrego and Garcia-Gil, 1994). Concentrations of unknown chlorophylls were calculated using the calibration coefficient of $\mathrm{Chl} \mathrm{a}$, and concentrations of unknown carotenoids using the calibration coefficient of $\beta, \beta$-carotene.

\section{Microscopy counts and identifications}

Protist samples were preserved with paraformaldehyde $(0.1 \%$ final concentration) and glutaraldehyde ( $1 \%$ final concentration) in duplicate $50 \mathrm{~mL}$ polypropylene centrifuge tubes and stored at $4{ }^{\circ} \mathrm{C}$ for up to 6 months in the dark until analysis; cellular features were well preserved and showed no evidence of degradation during storage. Protists were counted and identified using a combined system of fluorescence, Nomarski interference and Utermöhl sedimentation (FNU; Lovejoy and others, 1993). $60 \mathrm{~mL}$ samples $(16 \mathrm{~mL}$ for Lake B) were concentrated in Utermöhl sedimentation chambers for 24 hours and stained with DAPI $\left(0.1 \mu \mathrm{g} \mathrm{mL}^{-1}\right)$. Counts and identifications were made with a
Zeiss Axiovert 100 inverted epifluorescence microscope under 400 and $1000 \times$ magnification (cells $>2 \mu \mathrm{m}$ in diameter). Cells were identified to genus wherever possible and were classified as heterotrophic when no chloroplast was observed. Picocyanobacteria concentrations were determined by filtering $25-40 \mathrm{~mL}$ of the samples preserved for protists through Anodisc $0.2 \mu \mathrm{m}$ filters under gentle pressure, and mounting on microscope slides using immersion oil that were then stored at $-20^{\circ} \mathrm{C}$ until analysis. The cells were counted by epifluorescence microscopy at $1000 \times$ magnification with an Olympus 1 X71 inverted microscope fitted with blue and green excitation filters to detect the autofluorescence of photosynthetic pigments (Maclsaac and Stockner, 1993). A minimum of 400 cells and 15 fields were counted wherever possible.

\section{RESULTS}

\section{Climate}

The mean overall temperature from 2005 to 2008 was $-18.27^{\circ} \mathrm{C}$, and the mean summer (June-August) temperature for this 4 year period was $0.4^{\circ} \mathrm{C}$. Summer air temperatures were typically between -7 and $9^{\circ} \mathrm{C}$, but a maximum temperature of $20.5^{\circ} \mathrm{C}$ was recorded on 2 August 2008 (Fig. 2a), and ground temperatures at $20 \mathrm{~cm}$ at Lake $A$ rose above $0^{\circ} \mathrm{C}$ from early June to late August every year (Fig. 2b). Given the extreme latitude, daily totals of PAR fluctuated greatly over the year, with complete darkness from October until March (Fig. 2c). Cumulative PAR reaching Lake A was

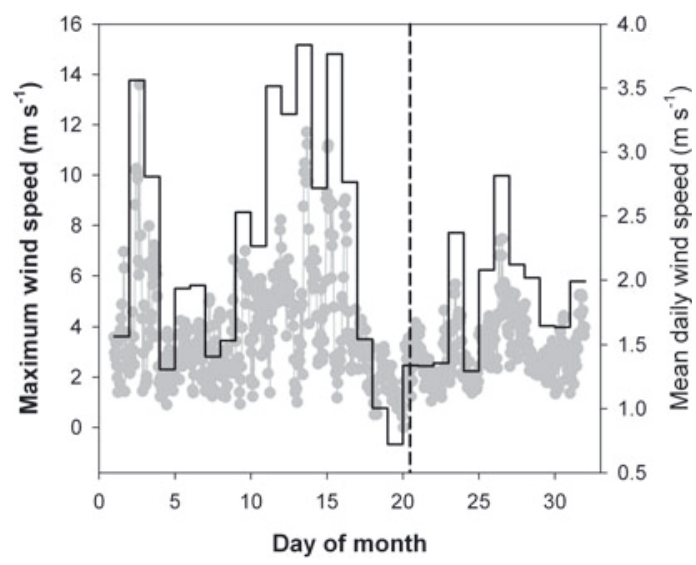

Fig. 3. The wind regime at Lake A during August 2008. Grey filled circles: maximum wind speed each hour. Black line: mean daily wind speed. The dashed line shows the time and date of profiling. 


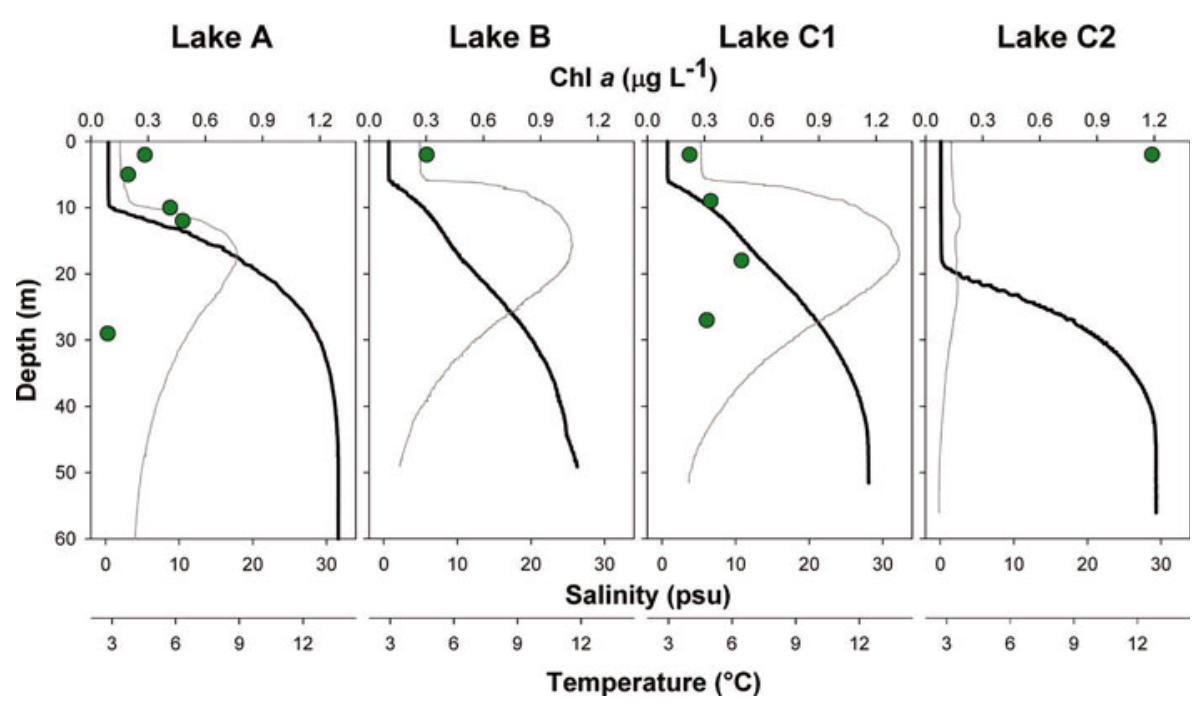

Fig. 4. Mixing in August 2008 for Lakes A, B, C1 and C2 from salinity (dark curves) and temperature (grey curves) profiles. Filled circles: $\mathrm{Chl}$ a concentrations, including the sum of all allomers, epimers and chlorophyllide a-like pigments.

1498 mol photons $\mathrm{m}^{-2}$ prior to sampling on 30 May and

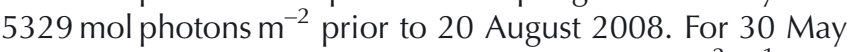
2008, the incident PAR was 53 molphotons $\mathrm{m}^{-2} \mathrm{~d}^{-1}$ and 0.38 mol photons $\mathrm{m}^{-2} \mathrm{~d}^{-1}$ reached underneath the ice, while on 20 August 2008 incident PAR was 33 mol photons $\mathrm{m}^{-2} \mathrm{~d}^{-1}$ and 30 mol photons $\mathrm{m}^{-2} \mathrm{~d}^{-1}$ immediately below the surface water. Mean water column PAR for the region 0-12 $\mathrm{m}$ (or from just under the ice to $12 \mathrm{~m}$ ) on the sampling days was $24 \%$ of the PAR under the ice or just below the water surface: $0.09 \mathrm{~mol}$ photons $\mathrm{m}^{-2} \mathrm{~d}^{-1}$ for 30 May and $7.23 \mathrm{~mol}$ photons $\mathrm{m}^{-2} \mathrm{~d}^{-1}$ in August during open-water conditions. Wind observations for the latter period in 2008 at Lake A showed two main episodes of high average wind speeds prior to the date of profiling (Fig. 3). Peak winds of up to $50 \mathrm{~km} \mathrm{~h}^{-1}$ were recorded in early August, and a second more prolonged episode of high average winds occurred in the period 9-17 August, with recorded maxima up to $43 \mathrm{~km} \mathrm{~h}^{-1}$. For the summer months July-September, the prevailing winds were from the north-northeast $\left(0-45^{\circ}\right)$, while the dominant winds $\left(>30 \mathrm{~km} \mathrm{~h}^{-1}\right)$ were from the west-northwest $\left(270-315^{\circ}\right)$.
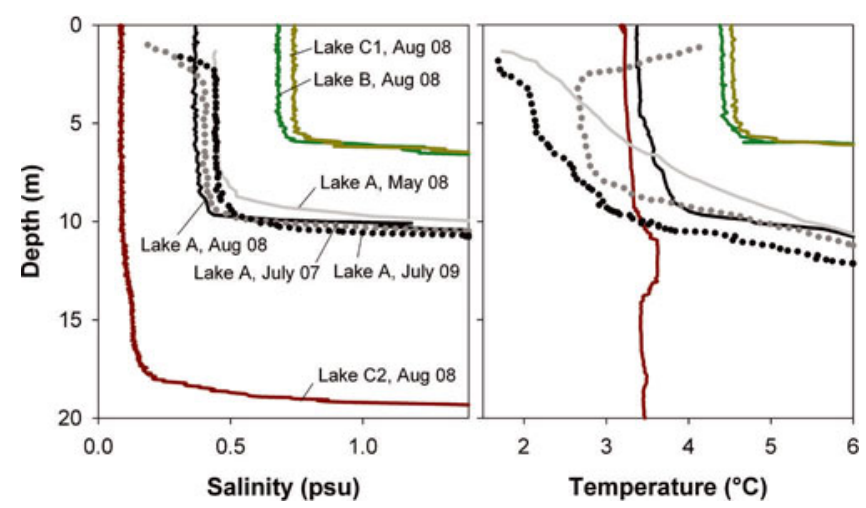

Fig. 5. CTD profiles for Lakes A, B, C1 and C2. Lake A had an ice cover of $1 \mathrm{~m}$ in July 2007, an ice cover of $1.2 \mathrm{~m}$ and $50 \mathrm{~cm}$ of snow in May 2008, and an ice cover of $1.6 \mathrm{~m}$ and $4 \mathrm{~cm}$ of snow in July 2009 .

\section{Ice cover}

Previous measurements have shown that ice cover varies greatly between and within years on the northern Ellesmere Island meromictic lakes. Lake A had a perennial, $2 \mathrm{~m}$ thick ice cover during late spring between 1969, when it was first measured, and 1999 (Table 1). Thinner ice covers were recently reported with thicknesses of 1.2-1.6 m before the onset of melt, and the lake was completely ice-free in August 2000 and 2008 and partially ice-free in 2003, 2006 and 2007 (Mueller and others, 2009; this study). Lakes B, C1 and C2 were also completely ice-free during the summers of 2000 and 2008 (Mueller and others, 2009; this study). Lake B was partially ice-free in 2003 and 2007, Lake C1 was partially ice-free in 2003 and completely ice-free in 2006, and Lake C2 was partially ice-free in 2003, 2006 and 2007 (Mueller and others, 2009).

\section{Water column structure and dynamics}

All four lakes had strong salinity gradients, with an upper layer of fresh water overlying salt water (Fig. 4). This upper layer had homogeneous salinity and temperature values during the open-water conditions of August 2008, suggestive of mixing (Figs 4 and 5). The freshwater layers of Lakes B and $\mathrm{C} 1$ were shallower $(\sim 6 \mathrm{~m})$ and slightly warmer $\left(\sim 4.5^{\circ} \mathrm{C}\right)$ than those of Lakes A and C2 (10 and $19 \mathrm{~m}$ respectively; $\sim 3.2^{\circ} \mathrm{C}$ ). Profiles of Lake A taken between July 2007 and July 2009 presented a continuum of conditions, from the presence of stratification through a completely homogeneous freshwater layer (Fig. 5). A stepped temperature profile in August 2008, compared to the monotonic increase in temperature observed in May 2008, suggests that mixing occurred between May and August 2008, and the salinity profiles suggest some erosion of the halocline to $11 \mathrm{~m}$, where the salinity values converge (Fig. 6). RADARSAT satellite images show that Lake A became entirely ice-free at some point between 6 and 12 August 2008 (D.R. Mueller, unpublished data), implying that the lake was potentially exposed to wind-induced mixing for up to 2 weeks prior to sampling. A slight decrease in salinity of the freshwater layer in August 2008 (0.37 psu) compared to May 2008 (0.44 psu) likely reflects the input of meltwater during summer; by July 

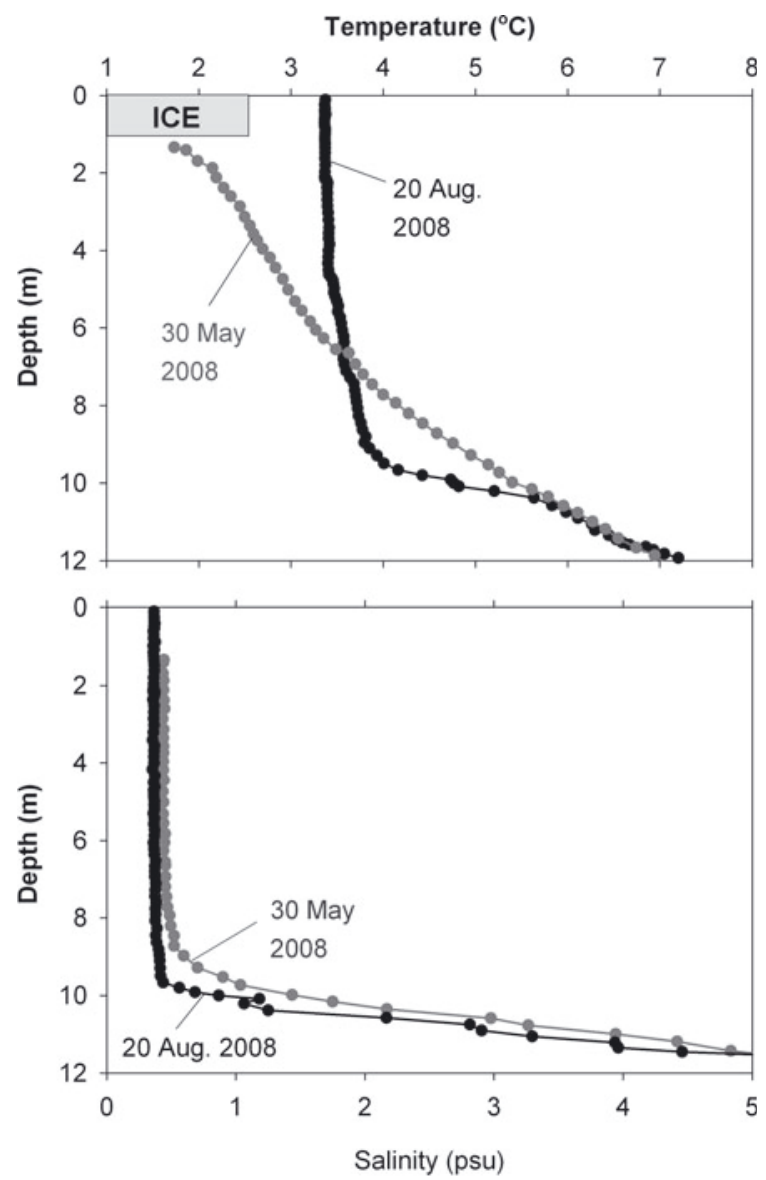

Fig. 6. CTD profiles for Lake A before (May) and during (August) open-water conditions in 2008.

2009 the salinity had returned to higher values (0.45 psu). Isohaline waters from 5 to $10 \mathrm{~m}$ in 2001 and 2008 suggested that mixing in Lake A extended to $10 \mathrm{~m}$ depth (Fig. 7), while reduced salinities at 11 and $12 \mathrm{~m}$ implied the penetration of mixing into the upper halocline during these years. As illustrated by the time series at $10 \mathrm{~m}$, due to diffusion the upper halocline returned to its prior salinity following mixing events. However, the highest salinities at 11 and $12 \mathrm{~m}$ were measured in May 2008; the mixing of August 2008 did not return them to the values measured in 2001 following the mixing of 2000. Salinity at $5 \mathrm{~m}$ appears to have remained relatively stable over the last 40 years, while

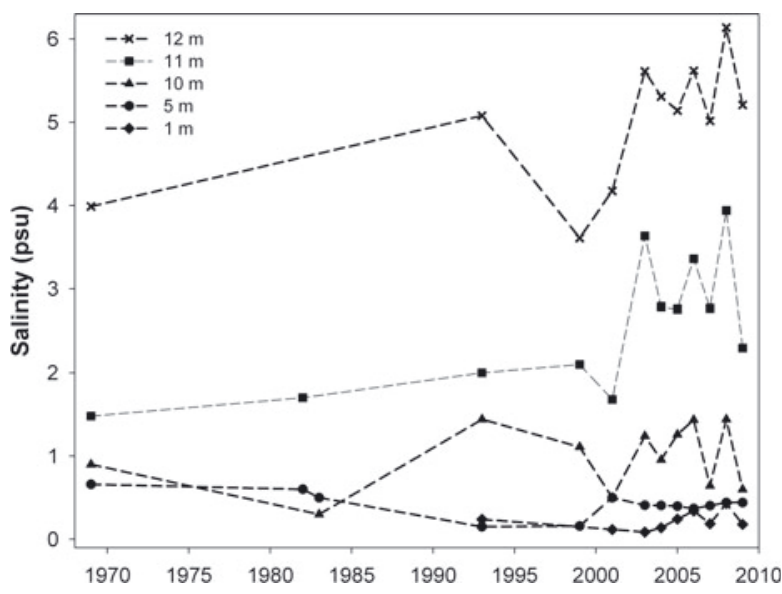

Fig. 7. Time series of salinity at different depths of Lake A from 1969 to 2009. All measurements were made with an ice cover (Table 1) and are the earliest available for every year. The vertical dashed lines indicate complete open-water conditions.

variations in salinity at $1 \mathrm{~m}$ are likely the result of seasonal inflow of stream water, combined with inputs from the melting lake ice.

The inflow and outflow salinities provided additional information about water movement (Table 2). The low salinity of inflows in July 2007 indicated that they were composed of water from the melting winter snowpack. However, the outflow of Lake A in July 2007 had a higher salinity than the lake water just underneath the ice $(0.41$ versus $0.19 \mathrm{psu}$ ). This has been observed in other Arctic lakes and has been suggested to be caused by the widening and thickening of the through-flow layer before exiting the lake, with the meltwater layer mixing with the upper meters of the water column (Bergmann and Welch, 1985). The high salinity of the outflows of Lakes B and A in August 2008 (0.83 and $0.39 \mathrm{psu}$ ) was consistent with mixing of their freshwater surface layers.

The estimated annual discharge of Lake A calculated from snowmelt and precipitation (but not including evaporation) was $6.96 \times 10^{6} \mathrm{~m}^{3} \mathrm{a}^{-1}$, while that calculated with the discharge data was $4.00 \times 10^{6} \mathrm{~m}^{3} \mathrm{a}^{-1}$ for a melt period of 2 weeks or $6.00 \times 10^{6} \mathrm{~m}^{3} \mathrm{a}^{-1}$ for a melt period of 3 weeks. The water residence time of the meltwater layer underneath the ice (from beneath the ice to $3 \mathrm{~m}$ depth) was estimated to be 1.2 years. This estimate must be considered an average

Table 2. Description of the inflows and outflow of Lake A, during or following the peak melt period. Inflow at the delta on 12 July 2007 was divided into two main streams, but the inflow at full freshet would be $\sim 100 \mathrm{~m}$ wide. Water salinity in Lake $\mathrm{A}$ just underneath the ice cover on 12 July 2007 was 0.19 psu, and the freshwater layer salinity was 0.37 psu on 24 August 2008

\begin{tabular}{|c|c|c|c|c|c|c|}
\hline \multirow[t]{3}{*}{ Site } & \multirow[t]{3}{*}{ Date } & \multicolumn{2}{|c|}{ Width } & \multirow{3}{*}{$\begin{array}{c}\text { Max. depth } \\
\text { m }\end{array}$} & \multirow{3}{*}{$\begin{array}{l}\text { Salinity } \\
\text { psu }\end{array}$} & \multirow{3}{*}{$\begin{array}{c}\text { Discharge } \\
\mathrm{m}^{3} \mathrm{~s}^{-1}\end{array}$} \\
\hline & & Flowing & Freshet & & & \\
\hline & & $\mathrm{m}$ & $\mathrm{m}$ & & & \\
\hline \multirow[t]{2}{*}{ Inflow at delta } & 12 Jul 2007 & (1) 6.8 & 100 & (1) 0.24 & 0.06 & 4.901 \\
\hline & & (2) 4.0 & & (2) 0.30 & & \\
\hline & 20 Aug 2008 & 1.1 & 8 & 0.09 & 0.83 & 0.064 \\
\hline \multirow[t]{2}{*}{ Outflow to sea } & 14 Jul 2007 & 9.0 & 9 & 0.38 & 0.41 & 3.306 \\
\hline & 20 Aug 2008 & 7.0 & 9 & 0.30 & 0.39 & 1.449 \\
\hline
\end{tabular}


Table 3. Concentration of nutrients in Lakes A, B, C1 and C2 measured in 2008. Unusually high values (in italics) were recorded at $10 \mathrm{~m}$ in Lake $\mathrm{A}$ (May) for $\mathrm{TN}$, and at $9 \mathrm{~m}$ in Lake $\mathrm{C} 1$ for $\mathrm{NO}_{3}{ }^{-}$ $\mathrm{NO}_{2}{ }^{-}$

\begin{tabular}{|c|c|c|c|c|c|c|}
\hline \multirow[t]{2}{*}{ Lake } & Depth & $\mathrm{TN}$ & TP & $\begin{array}{l}\mathrm{TN}: \mathrm{TP} \\
\text { ratio }\end{array}$ & $\mathrm{NO}_{3}{ }^{-}-\mathrm{NO}_{2}{ }^{-}$ & SRP \\
\hline & $\mathrm{m}$ & $\mu g \mathrm{~L}^{-1}$ & $\mu g \mathrm{~L}^{-1}$ & & $\mu g \mathrm{NL}^{-1}$ & $\mu g \mathrm{~L}^{-1}$ \\
\hline \multirow[t]{8}{*}{ A (May) } & 2 & 97 & 2.7 & 35.9 & $<5$ & 1.1 \\
\hline & 5 & 105 & 1.2 & 87.5 & $<5$ & 2.2 \\
\hline & 10 & 468 & 1.4 & 334.3 & 6 & 2.0 \\
\hline & 12 & 72 & 2.9 & 24.8 & 16 & 1.9 \\
\hline & 20 & $<14$ & 15.9 & 0.9 & 6 & 10.7 \\
\hline & 29 & 337 & 157 & 2.1 & 11 & 29.3 \\
\hline & 32 & 467 & 401 & 1.2 & 10 & 297 \\
\hline & 60 & 496 & 1200 & 0.4 & 8 & 1260 \\
\hline \multirow[t]{5}{*}{ A (Aug.) } & 2 & 80 & 2.5 & 32.0 & 13 & 1.1 \\
\hline & 5 & 93 & 2.5 & 37.2 & $<5$ & 1.0 \\
\hline & 10 & 107 & 3.4 & 31.5 & 8 & 1.4 \\
\hline & 12 & 109 & 3.6 & 30.3 & 10 & 1.7 \\
\hline & 29 & 4670 & 60.3 & 77.4 & 102 & 51.5 \\
\hline B (Aug.) & 2 & 113 & 1.5 & 75.3 & 7 & 1.3 \\
\hline \multirow[t]{4}{*}{ C1 (Aug.) } & 2 & 104 & 2.1 & 49.5 & 13 & 1.8 \\
\hline & 9 & 143 & 3.2 & 44.7 & 388 & 2.9 \\
\hline & 18 & 144 & 4.4 & 32.7 & 47 & 5.7 \\
\hline & 27 & 1610 & 13.8 & 116.7 & 21 & 8.5 \\
\hline C2 (Aug.) & 2 & 50 & 5.9 & 8.5 & 5 & 1.4 \\
\hline
\end{tabular}

value, as the meltwater layer immediately underneath the ice would be present throughout the melt season and therefore be renewed probably more than once during the same summer, while meltwater at $3 \mathrm{~m}$ would be present only at the climax of the melt season and therefore likely renewed more slowly than the 1.2 year average. Under perennially ice-cover conditions and no wind-induced mixing, there would be negligible renewal of water in the layer between 3 and $10 \mathrm{~m}$, while in the absence of ice and wind-induced mixing at least once per year to $10 \mathrm{~m}$, this layer would be replaced every 5.0 years.

The Brünt-Väisälä frequency, $N^{2}$, for the entire water column was $0.043 \mathrm{~s}^{-2}$. It rose to $0.103 \mathrm{~s}^{-2}$ when only the halocline $(10-30 \mathrm{~m})$ was considered, and was $0.030 \mathrm{~s}^{-2}$ for the surface layer. Relative to a reference criterion of stability of $0.020 \mathrm{~s}^{-2}$ (Caplanne and Laurion, 2008), these estimates indicate that the surface layer is much more prone to mixing than the entire water column due to the high stability of the halocline. $W$ values of 231 and 0.092 for the entire water column and the surface layer, respectively, were calculated. Values more than 100 generally suggest that wind energy is small compared to the strength of stratification while values less than 10 imply sensitivity to mixing.

Nutrient concentrations were low in the surface waters of the four sampled lakes (Table 3). Total nitrogen (TN) in August 2008 was $\sim 100 \mu \mathrm{g} \mathrm{L}^{-1}$, total phosphorus (TP) varied between 1 and $6 \mu \mathrm{g} \mathrm{L}^{-1}$, nitrate-nitrite ranged from below detection to $13 \mu \mathrm{g} \mathrm{L}^{-1}$, and soluble reactive phosphorus ranged from 1 to $2 \mu \mathrm{g} \mathrm{L}^{-1}$. The ratios of TN to TP in Lake A in May 2008 suggested phosphorus limitation in the surface waters but nitrogen limitation deeper in the water column. Nutrient concentrations were much higher in deeper water than in the surface waters, with TN five times greater and TP 400 times greater at $60 \mathrm{~m}$ than at $2 \mathrm{~m}$ at Lake A in May 2008. Total phosphorus stocks were estimated by trapezoidal

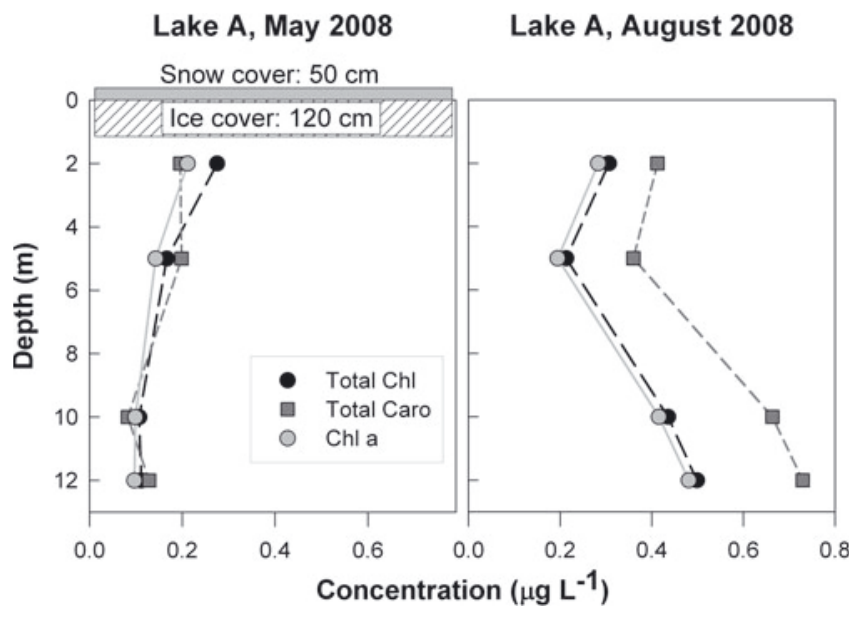

Fig. 8. Freshwater layer photosynthetic pigment concentration profiles for Lake A in May and August 2008. Chl a includes the sum of all allomers and epimers, and chlorophyllide a-like, and total chlorophylls and carotenoids include low concentration of unidentified chlorophylls and carotenoids, respectively.

integration for the depth region 2-12 $\mathrm{m}$ for the two sampling times at Lake A. These increased by $76 \%$ from May $\left(16.65 \mathrm{mg} \mathrm{TP} \mathrm{m}^{-2}\right.$ ) to August (29.25 $\mathrm{mg} \mathrm{TP} \mathrm{m}^{-2}$ ), implying entrainment of the deeper P-rich waters.

\section{Phototrophic communities}

The chlorophyll a (Chl a) profile of Lake A from May 2008 showed higher concentrations just under the ice $\left(0.21 \mu \mathrm{g} \mathrm{L}^{-1}\right)$ that then decreased with depth to $0.10 \mu \mathrm{g} \mathrm{L}^{-1}$ at 10 and $12 \mathrm{~m}$, with lower concentrations below, although there was a maximum in Chl a at 29-32 m (Fig. 8; Table 4). August 2008 was distinctly different, with peak concentrations of Chl a present at the bottom of the freshwater layer $\left(0.42 \mu \mathrm{g} \mathrm{L}^{-1}\right)$ and in the upper halocline $\left(0.48 \mu \mathrm{g} \mathrm{L}^{-1}\right)$, and minimal concentrations at $5 \mathrm{~m}\left(0.20 \mu \mathrm{g} \mathrm{L}^{-1}\right)$ and deeper in the water column (Figs 4 and 8; Table 4). Lake B $\left(0.30 \mu \mathrm{L} \mathrm{L}^{-1}\right)$ and Lake $\mathrm{C} 1\left(0.22 \mu \mathrm{L} \mathrm{L}^{-1}\right)$ had surface $\mathrm{Chl}$ a concentrations in August similar to Lake A, but Lake C2 had the highest value $\left(1.19 \mu \mathrm{g} \mathrm{L}^{-1}\right.$; Fig. 4). Our Chl a profiles for August indicated the presence of deep chlorophyll maxima in Lake $\mathrm{A}$ at $12 \mathrm{~m}$ and in Lake C1 at $18 \mathrm{~m}$ (Fig. 4). Total chlorophyll and total carotenoid concentrations were lower in May than in August in Lake A and followed the same pattern as Chl a with depth (Fig. 8). Cell abundances are another indicator of trophic status and generally reflected the same trends as Chl a, except for an anomalously low value at $12 \mathrm{~m}$ in August 2008 for Lake A (Table 5). On average, $86 \%$ of $\mathrm{Chl}$ a was in the picoplankton size fraction (73-104\%) in the topmost $12 \mathrm{~m}$ of Lake A in May 2008; all zeaxanthin was in this size fraction $(\geq 100 \%)$, while fucoxanthin picoplanktonic percentage varied greatly with depth $(45 \%$ to $>100 \%$, the latter reflecting analytical error at the limits of detection). Chl $b$ in the topmost $5 \mathrm{~m}$ was contained in larger cells (average 43\%) than at the bottom of the freshwater layer and in the upper halocline (average 105\%), and Chl c-related pigments were less associated with the picoplankton (39-78\%; Table 4). Picoplankton contributions equal to or greater than $100 \%$ indicate that this pigment is likely all within this size fraction. From $4 \%$ to $12 \%$ of chlorophylls were degradation products in the freshwater layers, indicating that the vast majority of production was occurring in situ, in contrast to 
Table 4. Pigment concentrations $\left(\mu \mathrm{g} \mathrm{L}^{-1}\right)$ measured in the water column of Lake $\mathrm{A}$ in May and August 2008. The values in italics give the $\%$ in the picoplankton fraction $(<3 \mu \mathrm{m})$. Note that $\mathrm{Chl}$ a includes the sum of all allomers and epimers, and chlorophyllide $a$-like; Chl $b$ includes the sum of all allomers and epimers. Chl $c_{1}$ : Chl $c_{1}$-like. Chl $c_{3}$ : Chl $c_{3}$-like. MgDVP: magnesium-2,4-divinyl phaeoporphyrin $a_{5}$ monomethyl ester. BChl e: bacteriochlorophyll-e. Fuco: fucoxanthin. Zea: zeaxanthin. $\beta, \beta$-Car: $\beta, \beta$-Carotene. Iso: isorenieratene-like. Degr. indicates the molar ratios in \% of degraded (i.e. allomers, epimers, chlorophyllide a, phaeophytin a) to undegraded chlorophylls (i.e. Chl and unknowns). ND: not detected

\begin{tabular}{|c|c|c|c|c|c|c|c|c|c|c|c|c|c|}
\hline \multirow[t]{2}{*}{ Depth } & \multicolumn{8}{|c|}{ Chlorophylls } & \multicolumn{4}{|c|}{ Carotenoids } & \multirow[t]{2}{*}{ Total } \\
\hline & $\mathrm{Chl} \mathrm{a}$ & $\mathrm{Chl} b$ & $\mathrm{Chl} c_{1}$ & $\mathrm{Chl} C_{2}$ & $\mathrm{Chl} C_{3}$ & MgDVP & Degr. & BChl e & Fuco & Zea & $\beta, \beta$-Car & Iso & \\
\hline \multicolumn{14}{|c|}{ May 2008} \\
\hline $2 \mathrm{~m}$ & $\begin{array}{c}0.211 \\
73\end{array}$ & $\begin{array}{c}0.015 \\
44\end{array}$ & $\begin{array}{c}0.017 \\
41\end{array}$ & $\begin{array}{c}0.018 \\
39\end{array}$ & $\begin{array}{c}<0.001 \\
41\end{array}$ & $\begin{array}{c}<0.001 \\
44\end{array}$ & $\begin{array}{l}12 \\
12\end{array}$ & $\begin{array}{l}\text { ND } \\
\text { ND }\end{array}$ & $\begin{array}{c}0.112 \\
86\end{array}$ & $\begin{array}{c}0.076 \\
106\end{array}$ & $\begin{array}{c}0.004 \\
223\end{array}$ & ND & 0.470 \\
\hline $5 \mathrm{~m}$ & $\begin{array}{c}0.143 \\
78\end{array}$ & $\begin{array}{c}0.003 \\
41\end{array}$ & $\begin{array}{c}0.007 \\
41\end{array}$ & $\begin{array}{c}0.009 \\
38\end{array}$ & $\begin{array}{c}<0.001 \\
28\end{array}$ & ND & 12 & ND & $\begin{array}{c}0.110 \\
45\end{array}$ & $\begin{array}{c}0.077 \\
102\end{array}$ & $\begin{array}{c}0.011 \\
129\end{array}$ & ND & 0.364 \\
\hline $10 \mathrm{~m}$ & $\begin{array}{c}0.099 \\
104\end{array}$ & $\begin{array}{c}0.001 \\
106\end{array}$ & $\begin{array}{c}0.003 \\
68\end{array}$ & $\begin{array}{c}0.002 \\
78\end{array}$ & ND & ND & 10 & ND & $\begin{array}{c}0.016 \\
230\end{array}$ & $\begin{array}{c}0.058 \\
100\end{array}$ & $\begin{array}{c}0.009 \\
103\end{array}$ & ND & 0.190 \\
\hline $12 \mathrm{~m}$ & $\begin{array}{c}0.097 \\
87\end{array}$ & $\begin{array}{c}0.001 \\
104\end{array}$ & $\begin{array}{c}0.005 \\
57\end{array}$ & $\begin{array}{c}0.006 \\
49\end{array}$ & ND & ND & 11 & ND & $\begin{array}{c}0.083 \\
56\end{array}$ & $\begin{array}{c}0.037 \\
118\end{array}$ & $\begin{array}{c}0.006 \\
126\end{array}$ & ND & 0.240 \\
\hline $20 m$ & $\begin{array}{c}0.032 \\
102\end{array}$ & $\begin{array}{c}0.006 \\
53\end{array}$ & ND & ND & ND & ND & 19 & $\begin{array}{c}0.316 \\
88\end{array}$ & ND & ND & ND & $\begin{array}{c}0.005 \\
136\end{array}$ & 0.393 \\
\hline $29 m$ & $\begin{array}{c}0.236 \\
102\end{array}$ & $\begin{array}{c}0.115 \\
96\end{array}$ & $\begin{array}{c}<0.001 \\
0\end{array}$ & ND & ND & $\begin{array}{c}<0.001 \\
0\end{array}$ & 54 & $\begin{array}{c}8.746 \\
104\end{array}$ & ND & ND & $\begin{array}{c}0.083 \\
101\end{array}$ & $\begin{array}{c}0.224 \\
115\end{array}$ & 9.912 \\
\hline $32 \mathrm{~m}$ & $\begin{array}{c}0.244 \\
85\end{array}$ & $\begin{array}{c}0.101 \\
77\end{array}$ & ND & ND & ND & ND & 56 & $\begin{array}{c}3.509 \\
84\end{array}$ & ND & ND & $\begin{array}{c}0.079 \\
73\end{array}$ & $\begin{array}{c}0.120 \\
76\end{array}$ & 4.396 \\
\hline $60 m$ & $\begin{array}{c}0.073 \\
79\end{array}$ & $\begin{array}{c}0.030 \\
68\end{array}$ & ND & ND & ND & ND & 42 & $\begin{array}{c}0.556 \\
98\end{array}$ & ND & ND & $\begin{array}{c}0.008 \\
162\end{array}$ & $\begin{array}{c}0.015 \\
66\end{array}$ & 0.738 \\
\hline \multicolumn{14}{|c|}{ August 2008} \\
\hline $2 \mathrm{~m}$ & 0.283 & 0.004 & 0.010 & $<0.001$ & 0.002 & ND & 12 & ND & 0.193 & 0.199 & 0.021 & ND & 0.719 \\
\hline $5 \mathrm{~m}$ & 0.195 & $<0.001$ & 0.007 & $<0.001$ & $<0.001$ & ND & 16 & ND & 0.145 & 0.199 & 0.016 & ND & 0.573 \\
\hline $10 m$ & 0.416 & 0.002 & 0.007 & 0.003 & ND & ND & 8 & ND & 0.113 & 0.489 & 0.036 & ND & 1.099 \\
\hline $12 \mathrm{~m}$ & 0.481 & 0.002 & 0.003 & 0.002 & ND & ND & 9 & ND & 0.043 & 0.632 & 0.040 & ND & 1.228 \\
\hline $29 \mathrm{~m}$ & 0.088 & 0.031 & ND & ND & ND & ND & 63 & 3.910 & ND & ND & 0.026 & 0.097 & 4.357 \\
\hline
\end{tabular}

deeper samples (below $29 \mathrm{~m}$ in Lake A and $27 \mathrm{~m}$ in Lake C1) where up to $63 \%$ of chlorophylls were degradation products, and likely resulted from phytoplankton senescence during sinking and accumulation in the salinity gradient.

The freshwater mixed layer contained a similar assemblage of pigments in May and August 2008, but their concentrations and relative importance differed over both time and depth (Fig. 9). Zeaxanthin concentrations were 2to 17-fold higher in August, with the greatest increases in the upper halocline region subject to mixing and nutrient enrichment. Conversely, $\mathrm{Chl} b, \mathrm{Chl} c_{1}$ and $\mathrm{Chl} c_{2}$ were detected in higher ratios relative to $\mathrm{Chl} a$ in May than in August at every depth. The fucoxanthin to $\mathrm{Chl}$ a ratio was similar in the uppermost $10 \mathrm{~m}$ in May and in August but was much greater at $12 \mathrm{~m}$ in May. Low concentrations of Chl $c_{3}$ were detected at 2 and $5 \mathrm{~m}$ at both sampling times, and MgDVP was only detected in trace amounts underneath the ice cover in May. Antheraxanthin was detected only at the bottom of the freshwater layer and in the upper halocline in August, where pigment peak concentrations occurred.

Microscopy enumerations of autotrophs in Lake A revealed some differences between May and August samples (Table 5). Chrysophytes were much more abundant in the uppermost $10 \mathrm{~m}$ in August, largely due to the widespread representation of cf. Kephyrion sp. Cryptophytes (Rhodomonas sp.), and dinoflagellates were also more abundant in August at every depth. Chlamydomonas sp. (chlorophyta) was identified at most depths at both sampling times, while a few Chroococcus sp. (cyanobacteria) were present in the
May surface sample. A large number of small, unidentified autotrophic cells were observed in Lake A from May samples. The picocyanobacterial enumerations for Lake $A$ revealed large differences between the two sampling dates. Populations increased by a factor of 3 , with highest concentrations $\left(1.65 \times 10^{8}\right.$ cells L $\left.^{-1}\right)$ in the upper halocline (Table 5$)$.

The photosynthetic pigment assemblages measured in the freshwater layers of Lakes A, B, C1 and C2 in August 2008 during ice-free conditions were similar, although some differences were also apparent (Fig. 10). Zeaxanthin was present in surface waters of all lakes, but its ratio to $\mathrm{Chl} a$ in Lake A (0.70) was twice those of the other lakes (0.25-0.31). $\mathrm{Chl} b$ was also detected in the surface waters of all lakes, but its relative importance was greater in Lake C2 (0.07) compared to Lakes A, C1 and C2 (0.01-0.03). Chl $c_{1}$ was present in similar proportions in all lakes, but $\mathrm{Chl} C_{2}$ ratios to $\mathrm{Chl}$ a were more than ten times greater in Lakes $\mathrm{B}, \mathrm{C} 1$ and C2 compared to Lake A. Chl $C_{3}$ was detected in only small amounts in Lakes $\mathrm{A}$ and $\mathrm{C} 2$, while trace concentrations of MgDVP were recorded only in Lake C2. The fucoxanthin contribution to total pigments was substantial in all lakes, but especially so in the surface waters of Lake C1. Violaxanthin was not detected in Lake $\mathrm{A}$ at any time of sampling but it was present in each of the other lakes. Diadinoxanthin and lutein were only detected in Lake C1, alloxanthin was present only in Lakes C1 and C2, and antheraxanthin was absent from Lake B.

Consistent with the observed differences in pigment composition, there were also large differences in the 
Table 5. Abundance of phytoplankton and other protists (in $10^{3}$ cells $\mathrm{L}^{-1}$ ) and picocyanobacteria (in $10^{6}$ cells L $^{-1}$ ). Lakes B, C1 and C2 were sampled in August

\begin{tabular}{|c|c|c|c|c|c|c|c|c|c|c|c|c|c|}
\hline \multirow[t]{2}{*}{ Taxa } & \multirow[t]{2}{*}{ Details } & \multicolumn{4}{|c|}{ A (May) } & \multicolumn{4}{|c|}{ A (August) } & \multirow{2}{*}{$\begin{array}{c}\text { B } \\
2 \mathrm{~m}\end{array}$} & \multicolumn{2}{|c|}{$\mathrm{C} 1$} & \multirow{2}{*}{$\begin{array}{l}\mathrm{C} 2 \\
2 \mathrm{~m}\end{array}$} \\
\hline & & $2 \mathrm{~m}$ & $5 \mathrm{~m}$ & $0 \mathrm{~m}$ & $12 \mathrm{~m}$ & $2 \mathrm{~m}$ & $5 \mathrm{~m}$ & $10 \mathrm{~m}$ & $12 \mathrm{~m}$ & & $2 \mathrm{~m}$ & $9 \mathrm{~m}$ & \\
\hline \multirow[t]{2}{*}{ Bacillariophyceae } & Pennales & 0 & 0 & 0 & 0 & 0 & 0 & 0 & 0 & 3 & 0 & 0 & 0 \\
\hline & Centrales & 0 & 0 & 0 & 0 & 0 & 0 & 0 & 0 & 0 & 0 & 0 & 57 \\
\hline \multirow[t]{3}{*}{ Chlorophyceae } & Chlamydomonas sp. & 12 & 1 & 1 & 0 & 3 & 7 & 1 & 3 & 2 & 0 & 0 & 13 \\
\hline & cf. Dictyosphaerium sp. & 0 & 0 & 0 & 0 & 0 & 0 & 0 & 0 & 0 & 0 & 0 & 30 \\
\hline & Tetraedron sp. & 0 & 0 & 0 & 0 & 0 & 0 & 0 & 0 & 65 & 0 & 1 & 8 \\
\hline Choanoflagellates & cf. Monosiga sp. & 1 & 4 & 11 & 0 & 0 & 0 & 0 & 0 & 0 & 0 & 0 & 0 \\
\hline \multirow[t]{7}{*}{ Chrysophyceae } & Chrysoikos cf. bicornis & 0 & 0 & 0 & 0 & 0 & 0 & 0 & 0 & 5 & 0 & 0 & 0 \\
\hline & Chrysolykos planctonicus & 0 & 0 & 0 & 0 & 0 & 0 & 0 & 0 & 0 & 29 & 0 & 7 \\
\hline & Chrysolykos skujae & 0 & 0 & 0 & 0 & 0 & 1 & 0 & 0 & 0 & 0 & 0 & 0 \\
\hline & cf. Erkenia subaequiciliata & 0 & 3 & 2 & 0 & 16 & 17 & 2 & 0 & 98 & 87 & 3 & 12 \\
\hline & (Pseudo) Kephyrion sp. & 0 & 0 & 0 & 0 & 199 & 126 & 215 & 3 & 217 & 146 & 0 & 108 \\
\hline & cf. Pseudopedinella sp. & 0 & 0 & 0 & 0 & 0 & 0 & 0 & 1 & 2 & 13 & 0 & 5 \\
\hline & Spiny cyst & 0 & 0 & 0 & 0 & 2 & 5 & 7 & 4 & 7 & 0 & 0 & 0 \\
\hline \multirow[t]{2}{*}{ Ciliate } & Peritrichs & 0 & 0 & 0 & 0 & 0 & 0 & 0 & 1 & 3 & 3 & 0 & 0 \\
\hline & Holotrichs & 0 & 0 & 0 & 0 & 0 & 0 & 0 & 0 & 0 & 0 & 0 & 2 \\
\hline \multirow[t]{2}{*}{ Cryptophyceae } & cf. Rhodomonas sp. & 2 & 3 & 1 & 2 & 9 & 9 & 19 & 6 & 44 & 47 & 30 & 97 \\
\hline & $5-10 \mu \mathrm{m}$ & 0 & 0 & 0 & 0 & 0 & 0 & 0 & 0 & 0 & 0 & 16 & 0 \\
\hline \multirow[t]{2}{*}{ Cyanobacteria } & cf. Chroococcus sp. & 3 & 0 & 0 & 0 & 0 & 0 & 0 & 0 & 0 & 0 & 0 & 0 \\
\hline & Filament & 0 & 0 & 0 & 0 & 0 & 0 & 0 & 0 & 0 & 0 & 0 & 16 \\
\hline \multirow[t]{2}{*}{ Dinophyceae } & Gymnodinium sp. & 0 & 0 & 0 & 2 & 1 & 0 & 3 & 1 & 0 & 2 & 1 & 27 \\
\hline & Peridinium sp. & 0 & 1 & 0 & 0 & 4 & 3 & 1 & 4 & 41 & 19 & 2 & 54 \\
\hline \multirow[t]{2}{*}{ Auto. cells } & Non-flagellate & 120 & 49 & 20 & 40 & 10 & 6 & 4 & 6 & 111 & 92 & 347 & 196 \\
\hline & Flagellate & 0 & 0 & 1 & 2 & 4 & 3 & 2 & 2 & 5 & 0 & 1 & 0 \\
\hline \multirow[t]{3}{*}{ Hetero. cells } & Non-flagellate & 1 & 0 & 0 & 0 & 5 & 1 & 1 & 1 & 3 & 4 & 1 & 1 \\
\hline & Flagellate & 0 & 0 & 0 & 0 & 29 & 36 & 8 & 0 & 0 & 1 & 0 & 3 \\
\hline & Heliozoan & 1 & 1 & 0 & 0 & 0 & 0 & 0 & 0 & 0 & 0 & 0 & 0 \\
\hline Total & & 143 & 65 & 38 & 54 & 315 & 264 & 299 & 74 & 634 & 449 & 410 & 700 \\
\hline Picocyanobacteria & & 23 & 23 & - & 9 & 60 & 74 & 165 & 13 & - & - & - & - \\
\hline
\end{tabular}

-: not determined.

microscopy enumerations among lakes (Table 5). Chrysophytes were abundant in all samples, except in the upper haloclines of Lakes A and C1. Diatoms were observed only in Lakes B and C2, while identified chlorophytes were largely absent from Lake C1. Cryptophytes and dinoflagellates were present in all samples but less abundant in Lake A, with maximal concentration in Lake C2. As in the surface sample for Lake $A$ in May, there were a large

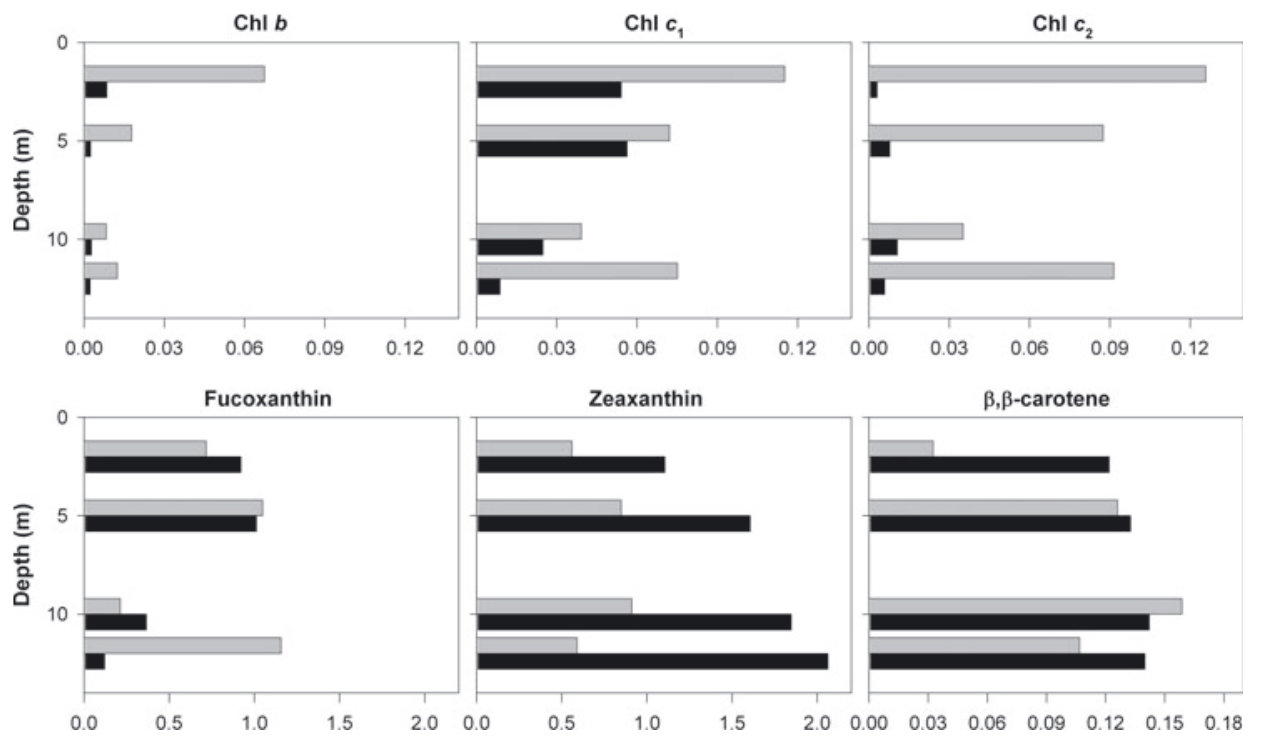

Fig. 9. Concentrations of photosynthetic pigments in Lake A in May and August 2008 expressed as molar ratios to Chl a. Grey bars represent May; black bars represent August. Note the different $x$-axis scales. Chl $b$ includes the sum of all allomers and epimers. Chl $c_{1}$ : Chl $c_{1}$-like. 

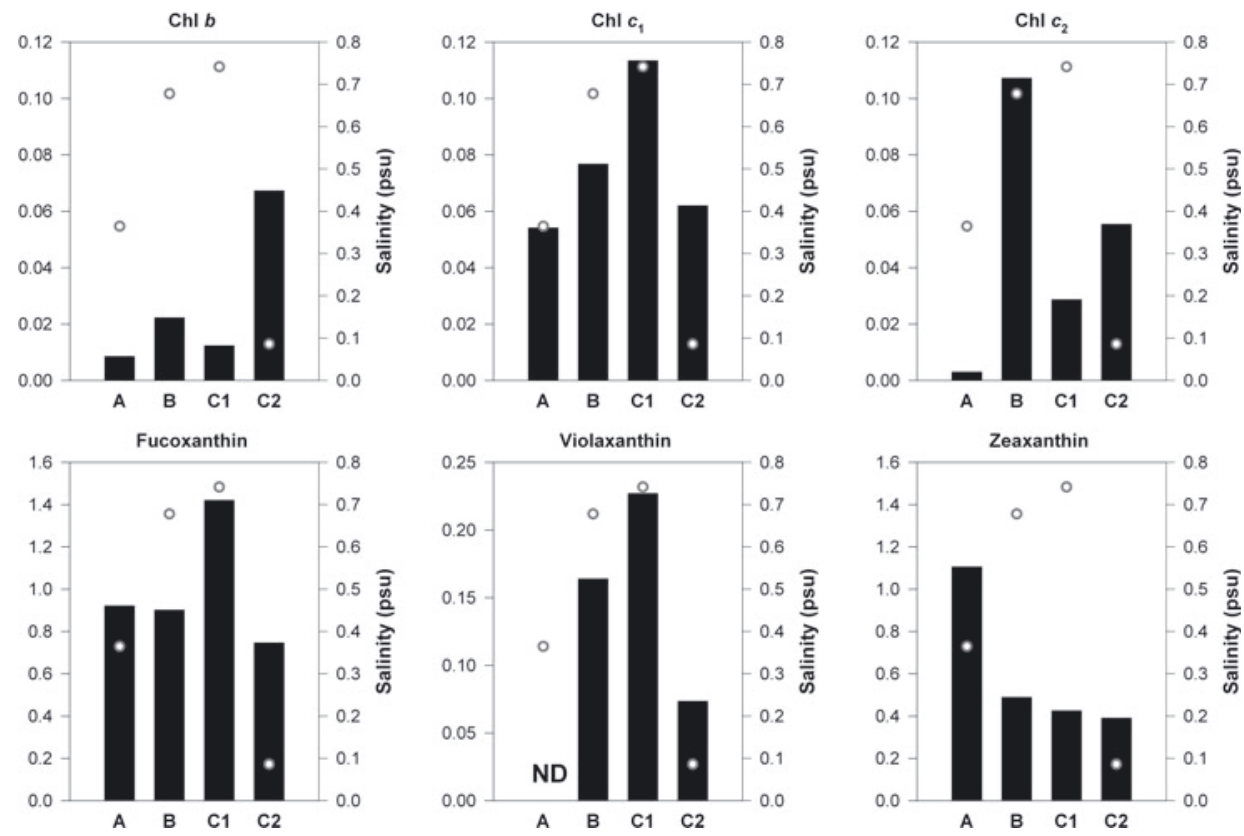

Fig. 10. Differences in surface $(2 \mathrm{~m})$ photosynthetic pigments of Lakes $A, B, C 1$ and $C 2$ in August 2008 expressed as molar ratios to Chl a on the left $y$-axis (note the differences in scales). Chl $b$ includes the sum of all allomers and epimers. Chl $c_{1}$ : Chl $c_{1}$-like. ND: not detected. Open circles: salinity in each lake at the depth of sampling.

number of small, autotrophic cells in Lakes B, C1 and C2 in August that could not be identified. Sediments were observed in the samples of Lakes A and C2 in August, suggesting the turbulent suspension of abiotic materials brought into the lakes from their catchments. Heterotrophic protists were identified in all samples (Table 5). Monosiga sp. (choanoflagellate) was the only heterotrophic flagellate observed in the freshwater layer of Lake A in May while ciliates were observed in low abundance in the August samples.

\section{DISCUSSION}

\section{Water column stratification}

The Ellesmere Island lakes are highly stratified as a result of strong salinity gradients and, until recently, perennial ice cover that prevented wind-induced mixing. Their freshwater oxic mixolimnia are derived from meltwater (e.g. Lake A: 0$10 \mathrm{~m}$ ) and are separated by haloclines from their marinederived anoxic monimolimnia (e.g. Lake A: $>30 \mathrm{~m}$ ), that are close to the salinity of sea water. The temperature profiles of these lakes can have two maxima: a small peak that is sometimes present just underneath the ice cover, likely resulting from solar heating or warm inflowing water (e.g. Lake A in July 2007, Fig. 5), and a deep water maximum (e.g. $8.88^{\circ} \mathrm{C}$ at $16.77 \mathrm{~m}$ in August 2008 in Lake A) as a result of solar radiation absorbed in the high-salinity water (Vincent and others, 2008b). It is notable that Lake A's thermal profile is strikingly similar to that of Lake Bonney, a perennially ice-capped lake in the McMurdo Dry Valleys, which has a temperature maximum of $6.4^{\circ} \mathrm{C}$ at $14-16 \mathrm{~m}$ (Spigel and Priscu, 1998). While Lake C2 did not show a deep temperature maximum in 2008, it had a relatively small maximum in 2001 (Mueller and others, 2009). This is consistent with the deeper halocline of Lake C2 and the observation that it loses its ice cover more frequently than Lakes A, B and C1.

\section{Water column dynamics}

The depth of the mixed layer of a lake depends on its exposure to wind, and additionally on the strength of its density stratification (Wetzel, 2001). Wind exposure is a function of fetch, wind speed and ice cover, with greater duration of ice-free conditions increasing the probability of mixing via high-wind events as well as by convective circulation. The duration of ice cover is likely to be a complex function of lake depth, snow cover, climate and topography (Vincent and others, 2008a). The importance of the latter factor is supported by comparisons with Lakes C1 and $\mathrm{C} 2$, which lose their ice covers more frequently than Lakes A and B despite a slightly cooler climate (Mueller and others, 2009). Lakes A and B are surrounded by steeper terrain that causes greater topographic shading and wind protection than at the $\mathrm{C}$ lakes. Differences in catchment size and the amount of relatively warm water that flows beneath the ice each year may also contribute to the differences in ice-out. The difference in mixing depth between Lake A $(10 \mathrm{~m})$ and Lake B $(6 \mathrm{~m})$ may similarly reflect a topographic control, with Lake A being less wind-protected than Lake B. However, it may also reflect differences in wind fetch: $3.5 \mathrm{~km}$ for Lake A but only $1 \mathrm{~km}$ for Lake B.

The depth and strength of the halocline in meromictic lakes is an additional control on the potential extent of wind-induced mixing after ice-out. The deeper mixed layer of Lake C2 $(19 \mathrm{~m})$ compared to Lake C1 $(6 \mathrm{~m})$ is likely a consequence of a larger catchment that contains glaciers, resulting in greater flushing of salts and erosion of the halocline. Similarly, the larger catchment of Lake A compared to Lake B contributes to its deeper mixing depth.

It has been suggested that Romulus Lake, a meromictic lake on Ellesmere Island located $300 \mathrm{~km}$ south of Lake A, has become hypersaline as a result of its seasonal ice cover; saline entrainment from the halocline results in brine plumes during freeze-up that sink to the monimolimnion (Van Hove and others, 2006). Could such processes also be occurring in 
northern coastal Ellesmere Island lakes? The salinity of the mixed layer is a balance between salt entrainment from the halocline and flushing via the outflow. The salinity of Lake A at $5 \mathrm{~m}$ appears to have been stable at $\sim 0.37$ psu since 1970 , which indicates that, up to now, freshwater inflows are sufficient to flush the salts entrained from the halocline during the episodic wind-induced mixing. Moreover, increases in annual precipitation over the Arctic are predicted with ongoing climate change (Walsh and others, 2005), which would increasingly flush out any salts entrained into the surface mixed layer. The salinity of the mixed layers of Lakes B, C1 and C2 is also low (i.e. $<1$ psu). Ellesmere Island's meromictic lakes range from those with low precipitation and catchment:volume (e.g. Romulus Lake) to those with much higher precipitation and catchment:volume (e.g. Lake C3), with the former potentially becoming hypersaline and the latter moving from meromixis to freshwater status (Van Hove and others, 2006). Over the long term, Lake A might become a freshwater lake if catchment inputs and precipitation remain sufficient to flush the salts from the mixed layer and reduced ice cover permits increased mixing and entrainment of salts from the monimolimnion.

The two different stability indices yielded similar estimates: the overall water column of Lake A was highly stratified, and full wind-induced mixing is unlikely; however, the surface layer is readily mixed. $N^{2}$ is a simple index but does not take into account the density profile of the full water column, nor the morphometry of the lake basin and wind conditions. The $W$ index includes these parameters in its calculation and is therefore more informative. None of these indices considered possible convection currents created by warming, including in the shallow moat region during summers when Lake A does not ice out completely. Thermohaline convection is another potential mixing mechanism under the ice in some meromictic lakes (e.g. Lake Vanda, Antarctica; Vincent and others 2008b). However, earlier data from Lake A during its perennial-ice phase provide no evidence of such effects. For example, in 1999 there was a gradient in salinity throughout the upper water column, and RADARSAT observations showed that the lake had been continuously covered by ice for at least the previous 5 years; however, after complete ice-out in 2000, the upper water column had homogeneous salinities, indicative of wind-induced mixing at that time (Mueller and others, 2009).

The nutrient profiles revealed that the monimolimnia of these meromictic lakes are huge nutrient reservoirs, compared to their surface waters where solar energy is in greatest supply for primary production. Similar nutrient levels have been previously reported from these lakes (Gibson and others, 2002; Van Hove and others, 2006) indicating that concentrations are stable on at least decadal timescales. The higher TP concentrations and total stocks in August than in May for Lake A could imply the entrainment of saline water, replete with nutrients, from the halocline, and rapid uptake by cells; however, the concentration changes are small in absolute terms and should be interpreted with caution. Predicted future warming is also projected to enhance surface runoff and increase external nutrient loading in Arctic lakes, which could enhance overall primary production (Wrona and others, 2006). The timing of melt is critical for these coastal lakes, and as long as freshet occurs while the lakes are ice-covered the through-flow conduit will deliver most of these nutrients directly to the outflow with minimal retention within the lake (Vincent and others, 2008a). Increases in optical constituents of the water (e.g. abiotic particles and dissolved materials) could greatly affect water transparency, reducing PAR penetration, but also protect the cells from damage caused by increased ultraviolet (UV) radiation (Vincent and others, 1998).

The cumulative PAR reaching Lake A was 3.6 times greater by August than by May, and this length of growing season up to the time of sampling may influence the observed phytoplankton community structure. The differences observed between May and August may therefore, at least in part, represent successional changes over the season. Differentiating these under-ice seasonal effects from the impacts of ice-out will require a comparison of late-summer profiles between years with and without ice cover. However, the effects of ice-out vastly exceeded the cumulative change in incident irradiance. PAR availability in the water column on 20 August 2008 was 80 times higher than on 30 May 2008, and the loss of perennial ice therefore has a dramatic effect on underwater energy supply for photosynthesis. This would allow the euphotic zone to extend deeper into the nutrient-rich waters of the monimolimnion, and this effect has been previously suggested to explain the long-term variations in photosynthetic bacterial populations in Lake A (Antoniades and others, 2009)

\section{Changes in phototrophic community structure during summer 2008 at Lake A}

Maximum $\mathrm{Chl}$ a concentrations in the freshwater layer of Lake A in August were more than twice those in May; however, this increase was modest relative to the pronounced change in water-column PAR in August caused by open-water conditions. The difference in the $\mathrm{Chl}$ a profiles between May and August implies resource limitation. In May, light may be the limiting variable as maximum $\mathrm{Chl}$ a concentrations occurred immediately below the ice, as observed in May 2005 and 2006 (Antoniades and others, 2009). In August, however, Chl a concentrations were much higher at the bottom of the freshwater layer and in the upper halocline, possibly due to entrainment of nutrient-rich deeper waters, while a $\mathrm{Chl}$ a maximum centered at 29$32 \mathrm{~m}$ may be the result of sinking and decomposing phytoplankton, given the high ratio of degraded to undegraded chlorophylls at these depths (Table 4).

Changes in the vertical distribution of phytoplankton in response to changing irradiances later in summer have also been observed in Antarctic meromictic lakes (Burch, 1988; McKnight and others, 2000). Under scenarios of reduced ice cover and higher wind-induced mixing, nutrient entrainment in the freshwater layer from bottom waters will become more frequent and may contribute to the presence of deep chlorophyll maxima at the bottom of the freshwater layer/upper halocline. Such populations will also be favoured by increased light penetration (see above). Deep chlorophyll maxima have been reported along the chemoclines in many meromictic lakes elsewhere, including in Antarctica (e.g. Roberts and others, 2000, 2004; reviewed in Lizotte, 2008). The components of the microbial food web (i.e. picocyanobacteria, phytoplankton, bacteria, nanoflagellates, ciliates and rotifers), given sufficient resource availability, and especially the picoplankton fraction $(0.2-2 \mu \mathrm{m})$, may also be positively influenced by warmer water temperatures, indicating that warmer climates will 
result in higher primary production (Rae and Vincent, 1998; Wrona and others, 2006). A study on the ecological implications of ice-cover decline of maritime Antarctic lakes since the 1950s also revealed increases in Chl a concentrations (1981-95), along with increases in water temperature and nutrient concentrations (Quayle and others, 2002). Grazing, diseases and flushing rates are likely to exert additional controls on primary production in polar lakes (Lizotte, 2008).

Photosynthetic pigment analyses showed that the composition of Lake A's phytoplankton community changed markedly between May and August (Fig. 9). Zeaxanthin, a signature pigment of cyanobacteria (also present in prochlorophytes and chlorophytes), was prevalent in Lake A during both sampling periods, and was significantly correlated with $\mathrm{Chl}$ a $(r=0.96, p<0.01, n=8)$, indicating the importance of cyanobacteria in Lake A. Cyanobacteria are a ubiquitous component of polar fresh and saline waters (Vincent, 2000; Powell and others, 2005; Van Hove and others, 2008). The increased zeaxanthin:Chl a ratios in August also suggested that cyanobacteria represented an even larger proportion of the phototrophic community during open-water conditions, although this may have been amplified by the greater zeaxanthin production relative to Chl a as a photoprotection strategy under increased irradiance (Schlüter and others, 2006). The large majority of cyanobacteria in Lake $\mathrm{A}$ are in the picoplankton size fraction (Table 4) as reported in numerous polar lakes (Hobbie and Laybourn-Parry, 2008), although the larger species Chroococcus sp. was also observed in low concentrations underneath the ice in May 2008 (Table 5). Picocyanobacterial counts for August 2008 (Table 5) were 60fold and 6-fold greater at 2 and $10 \mathrm{~m}$, respectively, than those reported for 1 August 2001 at the same depths (Van Hove and others, 2008) when Lake A had an ice cover of $1 \mathrm{~m}$. However, $\mathrm{Chl}$ a concentrations reported for the freshwater layer in August $2001\left(0.2-0.3 \mu \mathrm{g} \mathrm{L}^{-1}\right.$; Van Hove and others, 2008) were similar to those reported in August $2008\left(0.2-0.4 \mu \mathrm{g} \mathrm{L}^{-1}\right)$, suggesting that while picocyanobacteria had increased in abundance, total phytoplankton biomass remained largely unchanged. In meromictic Ace Lake, Antarctica, picocyanobacteria have been observed to similarly increase in abundance during improved irradiance conditions, and especially in the deeper waters (Powell and others, 2005), as in Lake A.

Potential sources of the $\mathrm{Chl} b$ and antheraxanthin detected in Lake A are chlorophytes, prasinophytes and/or euglenophytes, although these pigments are also produced by terrestrial higher plants. Chlorophytes, however, were the only one of these groups identified during microscopy. The maximum concentrations of $\mathrm{Chl} b$ immediately below the ice in May therefore reflect the importance of flagellated Chlamydomonas during low-light, low-turbulence conditions (Table 5). Motile organisms capable of positioning themselves near the ice bottom have competitive advantages when ice cover limits turbulence and light penetration. The main source of fucoxanthin and $\mathrm{Chl} c$-related pigments was likely chrysophytes, as diatoms were not observed by microscopy in the present study nor reported in previous studies of Lake A (Antoniades and others, 2009). Chrysophyte abundances were higher in August than in May, as indicated by fucoxanthin concentrations and microscopy counts (Tables 4 and 5), although ratios of fucoxanthin to Chl a changed little from early to late summer, indicating that the proportion of chrysophytes relative to total Lake A biomass was relatively stable. This success of chrysophytes through the summer may be related to their competitive ability at low phosphorus concentrations such as those found in Lake A. The detection of MgDVP, a Chl c-related pigment diagnostic of prasinophytes, underneath the ice cover in May 2008 indicates their likely presence in Lake A, although prasinoxanthin, another pigment diagnostic of prasinophytes, was below the detection limits of our HPLC.

\section{Phototrophic differences among lakes}

Surface Chl a concentrations measured in Lakes A, B and C1 in August 2008 were in the ultra-oligotrophic range and amongst the lowest reported concentrations for polar lakes (Lizotte, 2008). Many of the values of the present study are in the same range as those reported in previous studies of the same sites (Van Hove and others, 2008; Antoniades and others, 2009), indicating minimal interannual variability. However, the August 2008 Lake C2 Chl a concentration $\left(1.19 \mu \mathrm{L} \mathrm{L}^{-1}\right)$ falls at the lower range of oligotrophic lakes (Lizotte, 2008), in contrast to the ultra-oligotrophic value reported previously $\left(0.35 \mu \mathrm{g} \mathrm{L}^{-1}\right.$ in July 2001; Van Hove and others, 2008). The greater biomass in Lake C2 may be explained by its greater TP concentration and by the observation that this lake loses its ice cover more frequently than Lakes A, B and C1.

Pigment signatures and microscopy enumerations from the surface waters of all lakes sampled in August suggest that they contained cyanobacteria (zeaxanthin), green algae (Chl b, MgDVP, violaxanthin, lutein, zeaxanthin), chrysophytes (Chl $c_{2}, \mathrm{Chl} c_{3}$, fucoxanthin, diadinoxanthin), cryptophytes (Chl $c_{2}$, alloxanthin) and dinoflagellates $\left(\mathrm{Chl} C_{2}\right.$, diadinoxanthin). Diatoms were identified from microscopic analysis of Lakes B and C2 and confirmed by the presence of diatom pigment groups $\left(\mathrm{Chl} c_{1}, \mathrm{Chl} c_{2}\right.$, diadinoxanthin, fucoxanthin). Diatoms are currently rare in the plankton of these ecosystems but could become increasingly common in these lakes as reduced annual ice covers permit increases in windinduced turbulence, thus keeping heavy siliceous diatoms suspended in the water column (Roberts and others, 2004). Although most phytoplankton groups were present in every lake, they differed in their relative importance. Cyanobacteria were important in all these lakes, but especially in Lake A, consistent with the abundance of picocyanobacteria in many lakes throughout the polar regions (Vincent, 2000). Green algae were another common phytoplankton component that were slightly more abundant in the surface waters of Lake C2 (i.e. high ratio of $\mathrm{Chl} b$ to $\mathrm{Chl} a$, detection of MgDVP, many small autotrophic cells and identified chlorophytes). In Lake Bonney, Antarctica, green algae are similarly important, in particular the cold-adapted taxon Chlamydomonas (Morgan-Kiss and others, 2006). Chl $C_{2}$ was relatively much more important in Lakes B, C1 and C2 than in Lake $\mathrm{A}$ and indicated the greater representation of diatoms, chrysophytes, cryptophytes or dinoflagellates in these lakes. Lake $\mathrm{C} 2$ had high ratios of $\mathrm{Chl} c_{2}$ and alloxanthin to $\mathrm{Chl}$ a, agreeing with the observation of numerous individuals of Rhodomonas sp. (cryptophyte). One or more similar species of cryptophytes also occur as co-dominants in McMurdo Dry Valley lakes (Lizotte, 2008).

The large differences between the lakes in the present study are consistent with the variation in phytoplankton groups and taxa throughout the Arctic and Antarctica, even within specific regions such as the McMurdo Dry Valley 
lakes (Lizotte, 2008). These differences are likely the result of the interplay of many factors including seasonal and interannual variation, catchment and local climatic characteristics, species colonization, nutrient supply and trophic interactions. In addition to photosynthesis, several of these taxa could also use heterotrophy to supplement their supply in dissolved organic matter and nutrients (Hobbie and Laybourn-Parry, 2008) and to survive through the winter darkness (McKnight and others, 2000). Mixotrophic species are common among the phytoflagellates such as cryptophytes, chrysophytes, dinoflagellates and phototrophic ciliates and may respond to additional variables such as organic carbon availability and prey densities.

\section{Phytoplankton dynamics as an indicator of climate change}

Changes in primary productivity and in species composition can be reflective of climate change as polar lake ecology is typically dominated by bottom-up processes; the communities respond rapidly to changes in physicochemical characteristics (Roberts and others, 2004; Adrian and others, 2009). The changes in the phototrophic community structure associated with open-water conditions in Lake A provide a first representation of seasonal variability under conditions of extreme ice-cover variation. Although changes in population density and species composition have been observed over annual cycles in Antarctic lakes (Burch, 1988; Butler and others, 2000) and also in High Arctic Char Lake and Meretta Lake (Schindler and others, 1974a,b), this is the first time that such changes have been observed in a heretofore perennially ice-covered lake. Although one summer is too short a time frame to detect significant changes related to climate, this study provides insights into potential future changes associated with transition to seasonal ice cover in these ecosystems. Large interannual variability in phytoplankton species composition is common in polar lakes (Butler and others, 2000; McKnight and others, 2000). However, the phytoplankton communities in Lake A appear to be stable, based on photosynthetic pigment analyses from this and previous years (Antoniades and others, 2009), a fact likely related to the relative stability of stratification, limnological conditions, and icecover regimes until recent changes. The phytoplankton assemblage responses to climate change in these meromictic Ellesmere Island lakes are likely to be lake-specific, although general trends (e.g. increased biomass and productivity) are expected. Similarly in Antarctica, there are likely to be large differences in the response to loss of perennial ice cover (e.g. Lake Bonney and Lake Fryxell which lie in the same McMurdo dry valley but differ greatly in geochemistry and phytoplankton composition (Lizotte and Priscu, 1998)).

The linkages between climate change and lake biota are complex, as many factors such as light and nutrient availability, temperature, biotic interactions and species succession play a role in structuring the abundance and distribution of species, and responses can vary between systems. Despite these limitations, paleolimnological records from lakes in the circumpolar Arctic indicate extensive species changes in algae and invertebrate communities since 1850 that have been attributed to climate change (Smol and others, 2005; Antoniades and others, 2007). Loss of perennial ice cover may change or even destroy the vertical gradients in physical and chemical variables in polar meromictic lakes that allow niche partitioning down the water column (e.g. Pouliot and others, 2009). Shifts in phytoplankton community composition are also likely to have repercussions for higher trophic levels through changes in food availability (Prowse and others, 2006).

\section{ACKNOWLEDGEMENTS}

We thank $C$. Vallières for the protist enumeration and D. Mueller for drafting Figure 1. We also thank S. Bourget, S. Charvet, C. Chénard, T. Harding, A.D. Jungblut, J. Pouliot and the Parks Canada warden team for field assistance, and two anonymous referees for their insightful review comments. This research was funded by the Natural Sciences and Engineering Research Council of Canada (NSERC), the Networks of Centres of Excellence program ArcticNet, the Canada Research Chair program, the International Polar Year program MERGE-Canada, Ouranos and the W. Garfield Weston Foundation. We thank Parks Canada, the Polar Continental Shelf Project (PCSP) and the Northern Scientific Training Program (NSTP) for logistical and infrastructure support. This is PCSP/ÉPCP contribution No. 02710.

\section{REFERENCES}

Adrian, R. and 11 others. 2009. Lakes as sentinels of climate change. Limnol. Oceanogr., 54(6, pt 2), 2283-2297.

Anderson, N.J., R. Harriman, D.B. Ryves and S.T. Patrick. 2001. Dominant factors controlling variability in the ionic composition of West Greenland Lakes. Arct. Antarct. Alp. Res., 33(1), 418-425.

Antoniades, D. and 8 others. 2007. Abrupt environmental change in Canada's northernmost lake inferred from fossil diatom and pigment stratigraphy. Geophys. Res. Lett., 34(18), L18708. (10.1029/2007GL030947.)

Antoniades, D. and 7 others. 2009. Bacterial dominance of phototrophic communities in a High Arctic lake and its implications for paleoclimate analysis. Polar Sci., 3(3), 147-161.

Belzile, C., W.F. Vincent, J.A.E. Gibson and P. van Hove. 2001. Bio-optical characteristics of the snow, ice, and water column of a perennially ice-covered lake in the High Arctic. Can. J. Fish. Aquat. Sci., 58(12), 2405-2418.

Bergmann, M.A. and H.E. Welch. 1985. Spring meltwater mixing in small Arctic lakes. Can. J. Fish. Aquat. Sci., 42(11), 1789-1798.

Blake, W., Jr. 1989. Inferences concerning climatic change from a deeply frozen lake on Rundfjeld, Ellesmere Island, Arctic Canada. J. Paleolimnol., 2(1), 41-54.

Borrego, C.M. and L.J. Garcia-Gil. 1994. Separation of bacteriochlorophyll homologues from green photosynthetic sulfur bacteria by reversed-phase HPLC. Photosyn. Res., 41(1), 157-164.

Burch, M.D. 1988. Annual cycle of phytoplankton in Ace Lake, an ice covered, saline meromictic lake. Hydrobiologia, 165, 59-75.

Butler, H.G., M.G. Edworthy and C. Ellis-Evans. 2000. Temporal plankton dynamics in an oligotrophic maritime Antarctic lake. Freshwater Biol., 43(2), 215-230.

Caplanne, S. and I. Laurion. 2008. Effect of chromophoric dissolved organic matter on epilimnetic stratification in lakes. Aquatic Sci., 70(2), 123-133.

Doran, P.T., C.P. McKay, W.P. Adams, M.C. English, R.A. Wharton, Jr and M.A. Meyer. 1996. Climate forcing and thermal feedback of residual lake-ice covers in the high Arctic. Limnol. Oceanogr., 41(5), 839-848.

Doran, P.T., C.H. Fritsen, C.P. McKay, J.C. Priscu and E.E. Adams. 2003. Formation and character of an ancient 19-m ice cover and underlying trapped brine in an 'ice-sealed' East Antarctic lake. Proc. Natl Acad. Sci. USA (PNAS), 100(1), 26-31. 
Duguay, C.R., T.D. Prowse, B.R. Bonsal, R.D. Brown, M.P. Lacroix and P. Ménard. 2006. Recent trends in Canadian lake ice cover. Hydrol. Process., 20(4), 781-801.

Gibson, J.A.E. 1999. The meromictic lakes and stratified marine basins of the Vestfold Hills, East Antarctica. Antarct. Sci., 11(2), 175-192.

Gibson, J.A.E., W.F. Vincent, P. van Hove, C. Belzile, X. Wang and D. Muir. 2002. Geochemistry of ice-covered, meromictic Lake A in the Canadian High Arctic. Aquat. Geochem., 8(2), 97-119.

Green, W.J. and W.B. Lyons. 2009. The saline lakes of the McMurdo Dry Valleys, Antarctica. Aquat. Geochem., 15(1-2), 321-348.

Hattersley-Smith, G., J.E. Keys, H. Serson and J.E. Mielke. 1970. Density stratified lakes in northern Ellesmere Island. Nature, 225(5227), 55-56

Hobbie, J.E. 1984. Polar limnology. In Taub, F.B., ed. Lakes and reservoirs: ecosystems of the world. Amsterdam, Elsevier, 63-104.

Hobbie, J.E. and J. Laybourn-Parry. 2008. Heterotrophic microbial processes in polar lakes. In Vincent, W.F. and J. Laybourn-Parry, eds. Polar lakes and rivers: limnology of Arctic and Antarctic aquatic ecosystems. Oxford, etc., Oxford University Press, 197-212.

Jeffrey, S.W., R.F.C. Mantoura and S.W. Wright, eds. 1997. Phytoplankton pigments in oceanography: guidelines to modern methods. Second edition. Paris, UNESCO.

Jeffries, M.O. and H.R. Krouse. 1985. Isotopic and chemical investigations of two stratified lakes in the Canadian Arctic. Z. Gletscherkd. Glazialgeol., 21(1-2), 71-78.

Jeffries, M.O., H.R. Krouse, M.A. Shakur and S.A. Harris. 1984. Isotope geochemistry of stratified Lake ' $\mathrm{A}$ ', Ellesmere Island, N.W.T., Canada. Can. J. Earth Sci., 21(9), 1008-1017.

Kalff, J. 2003. Limnology: inland water ecosystems. Upper Saddle River, NJ, Prentice-Hall.

Kirk, J.T.O. 1994. Light and photosynthesis in aquatic ecosystems. Second edition. Cambridge, etc., Cambridge University Press.

Lizotte, M.P. 2008. Phytoplankton and primary production. In Vincent, W.F. and J. Laybourn-Parry, eds. Polar lakes and rivers: limnology of Arctic and Antarctic aquatic ecosystems. Oxford, etc., Oxford University Press.

Lizotte, M.P. and J.C. Priscu. 1998. Pigment analysis of the distribution, succession, and fate of phytoplankton in the McMurdo Dry Valley lakes of Antarctica. In Priscu, J.C., ed. Ecosystem dynamics in a polar desert: the McMurdo Dry Valleys, Antarctica. Washington, DC, American Geophysical Union, 229-239. (Antarctic Research Series 72.)

Lovejoy, C., W.F. Vincent, J.-J. Frenette and J.J. Dodson. 1993. Microbial gradients in a turbid estuary: application of a new method for protozoan community analysis. Limnol. Oceanogr., 38(6), 1295-1303.

Ludlam, S.D. 1996a. The comparative limnology of high arctic, coastal, meromictic lakes. J. Paleolimnol., 16(2), 111-131.

Ludlam, S.D. 1996b. Stratification patterns in Taconite Inlet, Ellesmere Island, N.W.T. J. Paleolimnol., 16(2), 205-215.

Maclsaac, E.A. and J.G. Stockner. 1993. Enumeration of phototrophic picoplankton by autofluorescence microscopy. In Kemp, P.F., B.F. Sherr, E.B. Sherr and J.J. Cole, eds. Handbook of methods in aquatic microbial ecology. Boca Raton, FL, Lewis.

Magnuson, J.J. and 13 others. 2000. Historical trends in lake and river ice cover in the northern hemisphere. Science, 289(5485), 1743-1746.

McKnight, D.M., B.L. Howes, C.D. Taylor and D.D. Goehringer. 2000. Phytoplankton dynamics in a stably stratified Antarctic lake during winter darkness. J. Phycol., 36(5), 852-861.

Michelutti, N., M.S.V. Douglas and J.P. Smol. 2003. Diatom response to recent climatic change in a high arctic lake (Char Lake, Cornwallis Island, Nunavut). Global Planet. Change, 38(3-4), 257-271.

Morgan-Kiss, R.M., J.C. Priscu, T. Pocock, L. Gudynaite-Savitch and N.P.A. Huner. 2006. Adaptation and acclimation of photosyn- thetic microorganisms to permanently cold environments. Microbiol. Mol. Biol. Rev., 70(1), 222-252.

Mueller, D.R., P. van Hove, D. Antoniades, M.O. Jeffries and W.F. Vincent. 2009. High Arctic lakes as sentinel ecosystems: cascading regime shifts in climate, ice-cover and mixing. Limnol. Oceanogr., 54(6, pt 2), 2371-2385.

Pawlowicz, R. 2008. Calculating the conductivity of natural waters. Limnol. Oceanogr. Meth., 6, 489-501.

Pouliot, J., P.E. Galand, C. Lovejoy and W.F. Vincent. 2009. Vertical structure of archaeal communities and the distribution of ammonia monooxygenase A gene variants in two meromictic High Arctic lakes. Environ. Microbiol., 11(3), 687-699.

Powell, L.M., J.P. Bowman, J.H. Skerratt, P.D. Franzmann and H.R. Burton. 2005. Ecology of a novel Synechococcus clade occurring in dense populations in saline Antarctic lakes. Mar. Ecol. Progr. Ser., 291, 65-80.

Prowse, T.D. and 6 others. 2006. Climate change effects on hydroecology of Arctic freshwater ecosystems. Ambio, 35(7), 347-358.

Quayle, W.C., L.S. Peck, H. Peat, J.C. Ellis-Evans and P.R. Harrigan. 2002. Extreme responses to climate change in Antarctic lakes. Science, 295(5555), 645.

Rae, R. and W.F. Vincent. 1998. Effects of temperature and ultraviolet radiation on microbial foodweb structure: potential responses to global change. Freshwater Biol., 40(4), 747-758.

Roberts, E.C., J. Laybourn-Parry, D.M. McKnight and G. Novarino. 2000. Stratification and dynamics of microbial loop communities in Lake Fryxell, Antarctica. Freshwater Biol., 44(4), 649-661.

Roberts, E.C., J.C. Priscu and J. Laybourn-Parry. 2004. Microplankton dynamics in a perennially ice-covered Antarctic lake: Lake Hoare. Freshwater Biol., 49(7), 853-869.

Schindler, D.W., J. Kalff, H.E. Welch, G.J. Brunskill, H. Kling and N. Kritsch. 1974a. Eutrophication in the High Arctic - Meretta Lake, Cornwallis Island $\left(75^{\circ} \mathrm{N}\right.$ lat.). J. Fish. Res. Board Can., 31(5), 647-662.

Schindler, D.W., H.E. Welch, J. Kalff, G.J. Brunskill and N. Kritsch. 1974b. Physical and chemical limnology of Char Lake, Cornwallis Island $\left(75^{\circ} \mathrm{N}\right.$ lat.). J. Fish. Res. Board Can., 31(5), 585-607.

Schlüter, L., T.L. Lauridsen, G. Krogh and T. Jørgensen. 2006. Identification and quantification of phytoplankton groups in lakes using new pigment ratios: a comparison between pigment analysis by HPLC and microscopy. Freshwater Biol., 51(8), 1474-1485.

Smol, J.P. and 25 others. 2005. Climate-driven regime shifts in the biological communities of arctic lakes. Proc. Natl Acad. Sci. USA (PNAS), 102(12), 4397-4402.

Spigel, R.H. and J.C. Priscu. 1998. Physical limnology of the McMurdo Dry Valley lakes. In Priscu, J.C., ed. Ecosystem dynamics in a polar desert: the McMurdo Dry Valleys, Antarctica. Washington, DC, American Geophysical Union, 153-187. (Antarctic Research Series 72.)

UNESCO. 1981. Tenth report of the Joint Panel on Oceanographic Tables and Standards. Paris, UNESCO, 17-19. (Technical Papers in Marine Science 36.)

Van Hove, P., C. Belzile, J.A.E. Gibson and W.F. Vincent. 2006. Coupled landscape-lake evolution in High Arctic Canada. Can. J. Earth Sci., 43(5), 533-546.

Van Hove, P., W.F. Vincent, P.E. Galand and A. Wilmotte. 2008. Abundance and diversity of picocyanobacteria in High Arctic lakes and fjords. Algol. Stud., 126(1), 209-227.

Vincent, A.C., D.R. Mueller and W.F. Vincent. 2008. Simulated heat storage in a perennially ice-covered high Arctic lake: sensitivity to climate change. J. Geophys. Res., 113(C4), C04036. (10.1029/2007JC004360.)

Vincent, W.F. 1983. Phytoplankton production and winter mixing: contrasting effects in two oligotrophic lakes. J. Ecol., 71(1), $1-20$.

Vincent, W.F. 2000. Cyanobacterial dominance in the polar regions. In Whitton, B.A. and M. Potts, eds. The ecology of 
cyanobacteria: their diversity in time and space. Dordrecht, Kluwer Academic, 321-340.

Vincent, W.F., I. Laurion and R. Pienitz. 1998. Arctic and Antarctic lakes as optical indicators of global change. Ann. Glaciol., 27, 691-696.

Vincent, W.F., J.E. Hobbie and J. Laybourn-Parry. 2008. Introduction to the limnology of high-latitude lake and river ecosystems. In Vincent, W.F. and J. Laybourn-Parry, eds. Polar lakes and rivers: limnology of Arctic and Antarctic aquatic ecosystems. Oxford, etc., Oxford University Press, 1-23.

Walsh, J.E. and 11 others. 2005. Cryosphere and hydrology. In Arctic Climate Impact Assessment - scientific report. Cambridge, etc., Cambridge University Press, 183-242.
Wetzel, R.G. 2001. Limnology: lake and river ecosystems. Third edition. San Diego, CA, Academic Press.

Wharton, R.A., C.P. McKay, G.D. Clow, D.T. Andersen, G.M. Simmons and F.G. Love. 1992. Changes in ice cover thickness and lake level of Lake Hoare, Antarctica: implications for local climate change. J. Geophys. Res., 97(C3), 3503-3513.

Wrona, F.J., T.D. Prowse, J.D. Reist, J.E. Hobbie, L.M.J. Lévesque and W.F. Vincent. 2006. Climate change effects on aquatic biota, ecosystem structure and function. Ambio, 35(7), 359-369.

Zapata, M., F. Rodríguez and J.L. Garrido. 2000. Separation of chlorophylls and carotenoids from marine phytoplankton: a new HPLC method using a reversed phase C8 column and pyridinecontaining mobile phases. Mar. Ecol. Progr. Ser., 195, 29-45. 